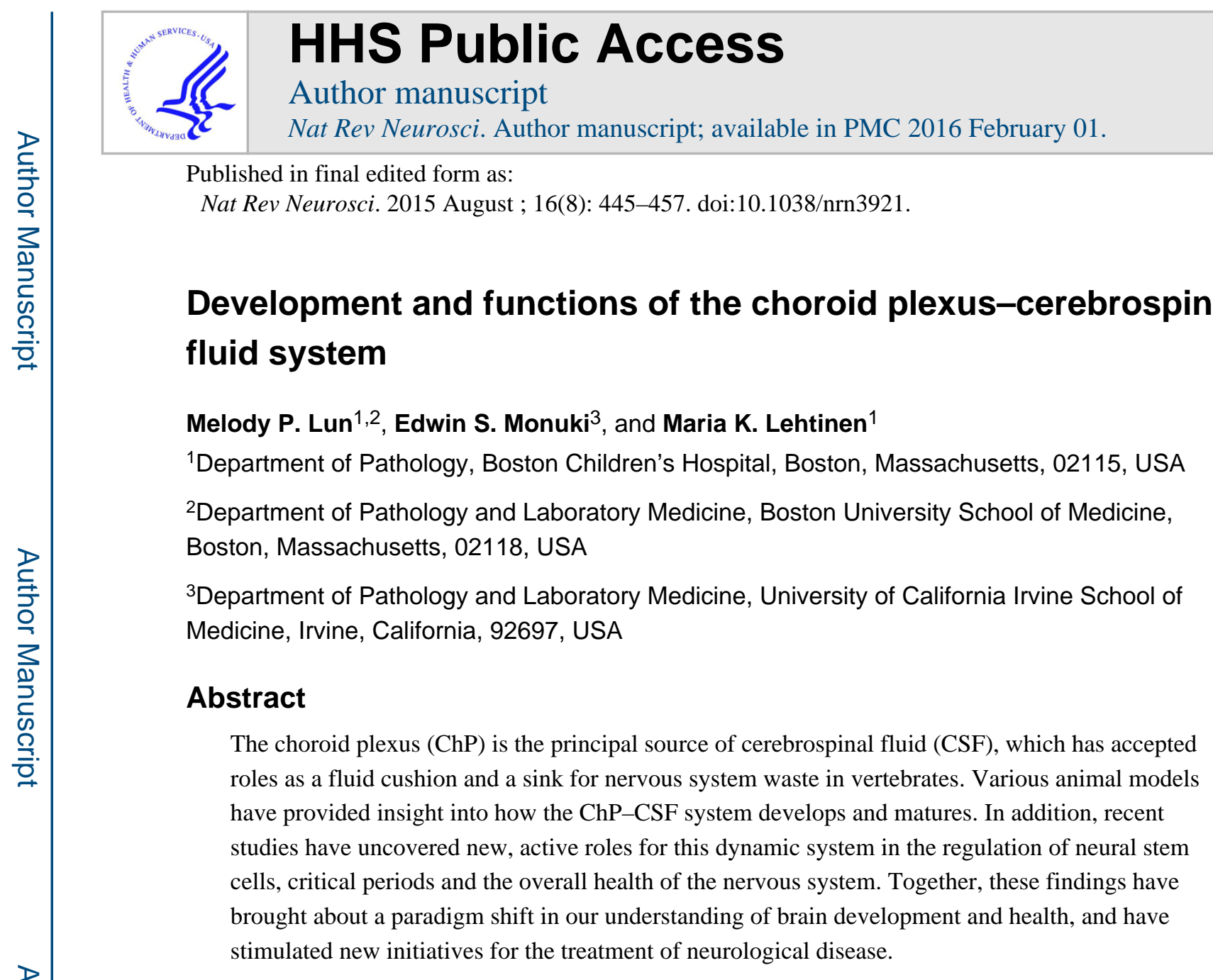

The choroid plexus (ChP) is a secretory tissue responsible for producing cerebrospinal fluid (CSF) in the vertebrate brain. CSF flows from the lateral to the third ventricle via the interventricular foramina (also known as the foramen of Monro), and then through the cerebral aqueduct to the fourth ventricle (FIG. 1). Subsequently, the CSF flows down the central canal of the spinal cord or circulates in the subarachnoid space, where it is resorbed by arachnoid villi and granulations 1,2 either by classical lymphatics in sinonasal tissues that underlie the cribriform plate ${ }^{3-5}$, or by the recently described meningeal-dural sinus lymphatics ${ }^{6}$ back into the systemic circulation or regional and cervical lymph nodes.

The ChP-CSF system is crucial for the development and maintenance of the CNS ${ }^{7-9}$. Despite the widely disparate complexity of the CNS across species, the ChP is an evolutionarily conserved structure that is present in lower vertebrates to humans ${ }^{10,11}$. Indeed, the function of the $\mathrm{ChP}$ appears to be conserved across species, as the $\mathrm{ChP}$ has been documented to secrete analogous signals, including growth factors, in various systems ${ }^{12}, 13$.

Landmark studies have demonstrated that appropriate $\mathrm{ChP}$ function is imperative for the formation and integrity of the CNS: too little CSF severely impairs brain growth, as CSF pressure is necessary for normal brain development ${ }^{14}$, whereas excess CSF - owing to

Correspondence to M.K.L., maria.lehtinen@childrens.harvard.edu.

Competing interests statement

The authors declare no competing interests. 
overproduction, obstructed flow or limited resorption of CSF - can lead to

hydrocephalus ${ }^{1,15}$. Excessive subarachnoid CSF may be an early marker of autism spectrum disorder ${ }^{16}$. However, despite the potential for the ChP-CSF system to regulate the CNS in a global manner, it remains one of the most understudied areas of neurobiology. Indeed, although the discovery that the $\mathrm{ChP}$ is responsible for CSF secretion was made over a century ago, the development and regulation of the ChP-CSF system are only beginning to be understood.

In this article, we first explore the early work elucidating the structure of the $\mathrm{ChP}$ and organization of its cell types. We next delve into the cell-intrinsic and -extrinsic molecular mechanisms that guide the specification of $\mathrm{ChP}$ cells and their proliferation into a highly structured organ. Last, we explore the impact of recent findings relating to the $\mathrm{ChP}$, specifically its participation in regulating neural stem cells of the embryonic and adult brain. Note that we include a brief discussion of the potential for ChP-targeted therapies in rejuvenating and repairing the CNS, as recent findings highlight these emerging possibilities. However, we refer the reader to several recent reviews on the $\mathrm{ChP}$ in ageing, disease and injury, and transport mechanisms in CSF production ${ }^{1,8,9,17-20}$. Together, this information should promote further investigation into the regulation of the $\mathrm{ChP}$ and its secreted factors, and the capacity to harness the potential of the $\mathrm{ChP}$ to repair the aged and diseased brain.

\section{Location and structure}

The ChP is a highly vascularized tissue that is located within each ventricle of the brain (FIG. 1). It develops from several locations along the dorsal axis of the neural tube. After neural tube closure, the hindbrain $\mathrm{ChP}$ of the fourth ventricle is the first to appear, followed by the synchronous development of the telencephalic $\mathrm{ChP}$ in each lateral ventricle and, finally, the diencephalic $\mathrm{ChP}$ of the third ventricle ${ }^{21-23}$. The diencephalic $\mathrm{ChP}$ is the last to appear, but histological analyses of human brain tissues suggest it completes differentiation earlier than the other $\mathrm{ChPs}^{11}$. Although the telencephalic $\mathrm{ChP}$ and diencephalic $\mathrm{ChP}$ initially emerge as distinct entities, the diencephalic tissue bifurcates during development, sending a branch through the intraventricular foramina and ultimately fusing into one continuous tissue with the telencephalic $\mathrm{ChP}^{11,21-23}$. The $\mathrm{ChP}$ is found in chordates above amphioxus (lancelet), and the order of ChP development seems to be conserved across species, despite enormous differences in gestational length ${ }^{21}$. However, although the gross appearance of the hindbrain $\mathrm{ChP}$ is similar among species, the appearance of the telencephalic $\mathrm{ChP}$ and diencephalic $\mathrm{ChP}$ varies considerably ${ }^{11}$. Much progress in the field stems from experiments performed in species as diverse as the spiny dogfish shark, sheep and marsupials, the latter of which confer the experimental benefit of having mostly postnatal development of the brain and thus the $\mathrm{ChP}^{24}$. However, harnessing newer technologies, including mouse genetics and proteomics, has enabled tremendous progress in our understanding of the development and specification of the ChP. Therefore, most ages referred to in this Review relate to mouse development.

The structure of the $\mathrm{ChP}$ reflects its secretory role. It consists of a monolayer of cuboidal epithelial cells that surrounds a stromal core of capillaries and connective tissue. Adjacent 
$\mathrm{ChP}$ epithelial cells are joined together by tight junctions to form the blood-CSF barrier that prevents paracellular free passage of molecules from the systemic circulation into the CSF. Together with adherens junctions, the tight junctions also ensure the apico-basal polarity of membrane proteins (for example, transporters) that are critical for normal epithelial cell function ${ }^{1}$. The identification of junctional, enzymatic and transporter proteins in the embryonic ChP suggests that barrier functions are present in the developing brain ${ }^{25,26}$. Experiments using injectable tracers suggest that these barrier functions are intact early in ChP development ${ }^{27-29}$. However, transcriptome studies have also revealed dynamic expression of transporters, indicating that the blood-CSF barrier changes during the course of development and provides differential neuroprotection or regulation of CSF production in the embryonic versus the mature brain ${ }^{26}$.

Depending on the location, the $\mathrm{ChP}$ receives its blood supply from either the anterior or posterior circulation. The anterior choroidal artery, which branches from the internal carotid or middle cerebral artery, supplies the telencephalic $\mathrm{ChP}$. The posterior choroidal artery, which branches from the posterior cerebral artery, feeds the telencephalic as well as the diencephalic choroid plexi. Finally, the anterior and posterior inferior cerebellar arteries, which originate from the basilar and vertebral arteries, supply the hindbrain $\mathrm{ChP}^{1}$. Blood flow and CSF secretion are thought to be regulated in part by sympathetic and parasympathetic innervation ${ }^{1,30-32}$. Unlike the endothelium in the brain's parenchyma, capillaries of the $\mathrm{ChP}$ are fenestrated. These endothelial fenestrae are connected by thin membranous diaphragms that are permeable to small molecules and water, thus enabling the rapid delivery of water via the blood to epithelial cells for CSF production. Solutes may cross from the blood into the stromal space by diffusion across endothelial fenestrae or by vesicular transport ${ }^{33}$. As with capillaries in other tissues, pericytes are found in the $\mathrm{ChP}$ and wrap around the endothelial cells. Finally, the ChP harbours various immune cells (BOX 1) and is considered a gateway for immune cell entry into the $\mathrm{CNS}^{34}$.

\section{Lineage specification and progenitors}

Studies of the molecular mechanisms that guide ChP development have typically focused on either the hindbrain or the telencephalic region. The diencephalic $\mathrm{ChP}$ has frequently been omitted, perhaps due to its relatively smaller size and/or more challenging dissection. It consists of three parts, and historically, the nomenclature for these parts has varied considerably. We refer to the work of Netsky and Shuangshoti ${ }^{11}$ in calling these three parts as the velum transversum (the anterior portion of the third ventricle), and the dorsal and ventral diencephalic plexus. Recent gene expression studies in rodent and primate tissues show that the hindbrain $\mathrm{ChP}$ and telencephalic $\mathrm{ChP}$ are spatially heterogeneous, and that their positional identities reflect their developmental origins along the rostral-caudal axis of the developing nervous system ${ }^{35}$. Nevertheless, the limited number of ultrastructural studies that have been performed on the ChPs from all four ventricles suggest that they all undergo identical developmental stages and the mature $\mathrm{ChP}$ epithelia are morphologically indistinguishable $27,36,37$.

Evidence from murine and avian systems indicate that $\mathrm{ChP}$ cell fate decisions are made early in development. In the murine brain, $\mathrm{ChP}$ specification occurs between embryonic day 
8.5 (E8.5) and E9.5 ${ }^{38}, 2-3$ days before overt differentiation is evident. Indeed, engraftment studies between chicken and quail show that $\mathrm{ChP}$ fate is determined up to 3 days before the anatomical appearance of the $\mathrm{ChP}^{39}$. Developmentally regulated proliferation in the hindbrain $\mathrm{ChP}$ is thought to be complete by the end of embryonic development ${ }^{40,41}$; however, it is not known whether proliferation in the telencephalic $\mathrm{ChP}$ and diencephalic $\mathrm{ChP}$ follows a similar developmental time course. As mature ChP epithelial cells are postmitotic, the rate of ongoing proliferation in the $\mathrm{ChP}$ diminishes dramatically in the adult brain $^{24}$. Nevertheless, there is evidence for proliferative cells in the adult $\mathrm{ChP}$ in rodents and in human patients following acute injury ${ }^{42,43}$ and in cancer ${ }^{44}$ (BOX 2).

ChP epithelium is derived from neuroepithelial cells, which are the multipotent stem cells of the nervous system, whereas the stromal component of the $\mathrm{ChP}$ is thought to be derived from head mesenchymal cells ${ }^{39}$. Specification of $\mathrm{ChP}$ epithelium from neuroepithelial cells seems to require the repression of neural cell fate. The antagonistic expression of Hesl, Hes 3 and Hes5, which encode basic helix-loop-helix (bHLH) transcription factors, versus neurogenin-2 (Ngn2; also known as Neurog2), leads to the specification of ChP epithelium versus Cajal-Retzius cells, respectively ${ }^{45}$. The inactivation of Hes 1, Hes 3 and Hes 5 leads to a failure in the development of telencephalic $\mathrm{ChP}$ and hindbrain $\mathrm{ChP}$, potentially through abrogation of bone morphogenetic protein (BMP) signalling ${ }^{45}$, 46 . In the absence of Hes expression, upregulation of the proneural Ngn2 inhibits ChP specification, instead increasing the production of Cajal-Retzius cells from the dorsal midline of the telencephalon ${ }^{45}$.

Similar observations have been made for other transcription factors that function to maintain $\mathrm{ChP}$ epithelial cell fate. LIM-homeobox protein LMX1A is expressed in the hindbrain rhombic lip and telencephalic cortical hem and functions in the normal specification of the roof plate ${ }^{47}$. In $\mathrm{Lmxla}^{-/-}$Dreher mice, the hindbrain roof plate does not form, leading to a failure of hindbrain ChP development ${ }^{48}$. In addition, LMX1A can also regulate later cellfate decisions, preventing ChP-specified cells from acquiring the fates of neighbouring cells ${ }^{47}$. LMX1A, in conjunction with BMP signalling, may repress LIM-homeodomain transcription factor 2 ( $L h x 2$ ) expression in the dorsal midline, thus excluding $L h x 2$ from the cortical hem and telencephalic ChP. By contrast, LHX2 is expressed in the cerebral cortex in a graded manner, and loss of $L h x 2$ expression in this region converts the cortex into expanded cortical hem and $\mathrm{ChP}^{49}$.

Other transcription factors have been implicated in the repression of $\mathrm{ChP}$ cell fate and regulation of ChP maintenance and survival. For example, overexpression of EMX2 in chicks suppresses telencephalic $\mathrm{ChP}$ development, which is consistent with the normal absence of EMX2 from ChP progenitors ${ }^{50}$. However, deletion of $O t x 2$ at E9 in mice leads to failure of the development of all ChPs, but its deletion at E15 affects only development of the hindbrain ChP, suggesting that OTX2 has multiple, temporally regulated functions in the $\mathrm{ChP}^{51}$.

Additional markers of the presumptive $\mathrm{ChP}$ region include tropomyosins, which are actin regulatory proteins that demarcate the sites of ChP formation at least 2 days before its appearance ${ }^{52}$. Tropomyosin-expressing neuroepithelial cells and microtubule-associated protein 2-expressing neuroepithelial cells, which are destined to become neurons, are 
mutually exclusive, suggesting that neuroepithelial cells with $\mathrm{ChP}$ cell fate are segregated by E15 in rats. Tropomyosin expression is concentrated in cells forming the segmental boundaries between prosomeres, rhombomeres and other neuroepithelial regions undergoing evagination, suggesting that tropomyosins may function to modulate cell shape and motility 52 .

\section{Hindbrain choroid plexus progenitors}

The hindbrain $\mathrm{ChP}$ is the first to develop: it emerges as bilateral crests from the roof of the hindbrain that connect at the midline by E14.5 in mice ${ }^{41}$. The primary progenitor domain for the hindbrain $\mathrm{ChP}$ is the rhombic lip, which is a germinal matrix that initially appears as a thin strip of cells along the dorsal midline of the neural tube following neural tube closure and that flares out and expands as the neural tube bends.

The rhombic lip can be subdivided into upper and lower structures ${ }^{40,53,54}$ (FIG. 2). The upper rhombic lip contributes largely to cerebellar development, but the lower rhombic lip, which is located between the medulla and the developing $\mathrm{ChP}$, generates a diverse set of cell types, including the epithelial cells of the hindbrain ChP. Rhombic lip progenitor cells display graded Wnt1 expression, and it is the cells expressing high levels of Wntl that give rise to the hindbrain roof plate epithelium (hRPe), a transient pseudostratified epithelium that covers the roof of the fourth ventricle ${ }^{40,53}$. Early studies suggested a model in which $\mathrm{ChP}$ development followed a linear progression of differentiation. Rhombic lip progenitors were thought to produce a non-mitotic population of hRPe cells, which then underwent a series of stereotyped morphological changes (stages I-IV; see below and FIG. 3), without the addition of more cells, to ultimately transform into the mature hindbrain ChP epithelium $^{21,22,38,39,55}$. Although epithelial transformation is an important aspect of $\mathrm{ChP}$ development, recent studies have elucidated molecularly and temporally distinct fields of cells in the lower rhombic lip and hRPe that contribute to hindbrain ChP development ${ }^{40,53}$.

Fate-mapping studies have revealed that the hRPe consists of three molecularly distinct fields of cells, which emerge at different developmental times and have unique organizational and proliferative programmes ${ }^{40}$. Field 1 cells populate the dorsal midline from E8 to E9.5. They express Wnt1 and are mitotic until about E10.5, but are not thought to contribute to $\mathrm{ChP}$ epithelium. By contrast, field 2 and field 3 cells form more laterally at E9.5, express Wnt1 and growth differentiation factor 7 ( $G d f 7$ ), are post-mitotic, and contribute to hindbrain $\mathrm{ChP}$ epithelium. Field 2 cells derive from rhombomeres 2-8, whereas field 3 cells derive from rhombomere 1. Field 2 cells express markers of mature $\mathrm{ChP}$ epithelial cells including transthyretin and the potassium voltage-gated channel subfamily E member 2 (Kcne2) as early as E9.5, whereas the expression of these genes is delayed in field 3 cells until E12.5 $5^{40}$. The mechanisms that regulate the appearance of these patterned, segmented fields of cells are not known. The hRPe is transient in development and ceases to contribute to the hindbrain $\mathrm{ChP}$ by $\sim \mathrm{E} 12.5$. Intriguingly, further genetic analyses have shown that, from E12.5 to E14.5, the lower rhombic lip can directly contribute to the hindbrain $\mathrm{ChP}$, when the hRPe no longer exists ${ }^{40}$. As the temporal interval for hindbrain $\mathrm{ChP}$ production continues well past E14.5, these findings have spurred further investigation into the source of hindbrain $\mathrm{ChP}$ progenitor cells.

Nat Rev Neurosci. Author manuscript; available in PMC 2016 February 01. 
Taking advantage of mouse genetic approaches to selectively target sonic hedgehog protein (SHH) expression in hindbrain ChP epithelial cells using Wnt1-Cre mice, recent studies have identified a third progenitor cell domain for the hindbrain $\mathrm{ChP}$ that is positioned between the anterior edge of the lower rhombic lip and the differentiated hindbrain $\mathrm{ChP}^{41}$. This persisting mitotic region, which consists of LMX1A- and GLI1-expressing ChP progenitor cells, produces ChP epithelial cells from E12.5 to the late stages of mouse embryonic development. These progenitor cells proliferate in response to SHH exposure, which is expressed by the hindbrain $\mathrm{ChP}$ epithelial cells. Thus, these findings suggest the existence of an autoregulatory loop in which mature $\mathrm{ChP}$ epithelial cells produce $\mathrm{SHH}$, which stimulates the proliferation of adjacent $\mathrm{ChP}$ epithelial cells. As these progenitor cells become post-mitotic, they progressively integrate into the adjacent $\mathrm{ChP}$ epithelium ${ }^{41}$.

Genetic fate-mapping studies not only have revealed that the roof plate is the source of progenitors for the hindbrain $\mathrm{ChP}$ but also have demonstrated that there is molecular heterogeneity in the roof plate epithelium, which may persist in the mature $\mathrm{ChP}^{53}$. Genetic lineage studies have verified that the hindbrain $\mathrm{ChP}$ receives contributions from rhombomeres 1 to $8^{40,53,54,56}$. Furthermore, fate-mapping studies have illustrated that the embryonic roof plate, unlike the floor plate, develops in a segmental, lineage-restricted fashion from Wntl-expressing neuroepithelial cells of discrete rhombomeric coordinates ${ }^{53}$. This genetic approach demonstrates that Wnt1-expressing cells from rhombomere 2 (Hoxa2lineage) and rhombomeres 3 and 5 (Egr2-lineage) from distinct axial regions do not intermingle in the mature $\mathrm{ChP}$. This segregation of lineages in the mature $\mathrm{ChP}$ may provide a basis for distinct functional domains within the mature hindbrain $\mathrm{ChP}$ with regards to CSF production and other functions. Consistent with this model, the regionalization of SHHexpressing cells that is observed in the developing hindbrain ChP may persist in adulthood $^{53}$, and even neighbouring cells differ in their expression of $\gamma$-protocadherin, a cell adhesion molecule that is found on the apical surface of ChP epithelium and that might have a role in CSF production ${ }^{57}$. There have been suggestions that ChPs differ in their metabolic rates and adrenergic activity ${ }^{58,59}$. However, the functional significance of a molecularly segregated $\mathrm{ChP}$ remains to be explored.

Little is known regarding secreted signalling factors that regulate the proliferation of $\mathrm{ChP}$ progenitor zones. However, in addition to $\mathrm{SHH}^{41}$ mentioned above, the Notch signalling pathway is able to stimulate hindbrain $\mathrm{ChP}$ epithelial proliferation ${ }^{40}$. Notch ligands are expressed by the developing mammalian $\mathrm{ChP}^{60}$. In the zebrafish mutant $m i b^{t f i 91}$, disruption in Notch signalling leads to formation of a misplaced and diminutive hindbrain $\mathrm{ChP}^{61}$. However, investigation of Notch signalling in zebrafish ChP development has also suggested that knockdown of Notch signaling in notchlb, deltaA and deltaD mutants leads to expansion of the hindbrain $\mathrm{ChP}^{62}$. These differential effects of Notch on ChP development may arise because Notch influences the entirety of the rhombic lip or directly affects $\mathrm{ChP}$ progenitors ${ }^{41}$. Intriguingly, the activated NOTCH3 receptor is also implicated as an oncoprotein in human $\mathrm{ChP}$ tumours ${ }^{44,63,64}$ (BOX 2). 


\section{Telencephalic choroid plexus progenitors}

The telencephalic $\mathrm{ChP}$ emerges between the medial wall of each telencephalic vesicle (FIG.

2). The telencephalic ChP develops simultaneously on both sides of the medial wall such that each lateral ventricle has its own $\mathrm{ChP}$ tissue. It undergoes a distal to proximal maturation process in which proliferative cells at the root of the plexus are progressively added to the growing tissue that extends into the ventricle ${ }^{24,65,66}$. Bromodeoxyuridine (BrdU) injection studies performed in the marsupial Monodelphis domestica (gray shorttailed opossum) show that newly postmitotic epithelial cells gradually incorporate into the growing ChP tissue along the dorsal stalk of the plexus ${ }^{24}$. In these studies, neither BrdUpositive progenitors nor newly postmitotic cells were observed in the ventral region of the $\mathrm{ChP}$. In conjunction with proliferative activity, the neuroepithelium comprising the midline choroid plaque also undergoes cell death, such that this region thins during the course of development in mice 23,67 .

The dorsal midline is a well-established patterning and signalling centre, which provides a source of BMPs that is critical for telencephalic ChP formation. It is thought that high levels of BMPs are required to induce $\mathrm{ChP}$ formation ${ }^{49,} 67,68$ and that BMPs might control telencephalic $\mathrm{ChP}$ morphogenesis by regulating the balance between cell proliferation and cell death to produce an epithelial monolayer ${ }^{67}$. By in situ hybridization, co-expression of Bmp2, Bmp4, Bmp5, Bmp6, and Bmp7 correlates with sites of ChP differentiation and with expression of the gene encoding forkhead box protein J1, a transcription factor involved in ciliogenesis ${ }^{67,69}$. Misexpression of the constitutively active BMP receptor type 1A (BMPR1A) leads to expansion of an epithelium that resembles the telencephalic ChP epithelium at the expense of cortical neuroepithelium ${ }^{70}$, whereas inactivation of BMPR1A leads to defective specification of telencephalic ChP epithelium ${ }^{46,71}$. A high level of BMP expression also represses LHX2, a suppressor of ChP epithelial and cortical hem fates ${ }^{49}$. The sufficiency of BMP signalling in ChP induction has been demonstrated by the differentiation of mouse and human embryonic stem cells into $\mathrm{ChP}$ epithelial cells using BMP4 ${ }^{68}$.

The telencephalic $\mathrm{ChP}$ in humans has anterior and posterior domains ${ }^{72}$, and fate-mapping studies taking advantage of $\mathrm{Gdf7}$-Cre mice suggest that the anterior-posterior substructure is likely to be conserved across species ${ }^{23}$. The anterior telencephalic $\mathrm{ChP}$ can be identified by its descent from the $G d f 7$ lineage, whereas the larger posterior domain is devoid of Gdf7lineage cells ${ }^{23}$. The boundary between the anterior and posterior domains of the mouse telencephalic $\mathrm{ChP}$ is not morphologically discernible. However, another distinguishing feature between these two domains is that the anterior domain shows evidence for developmentally regulated apoptosis at E10.5 and E11.5, whereas the posterior domain lacks TUNEL-positive cells ${ }^{23}$. Early $G d f 7$-mediated ablations achieved by driving diphtheria toxin A (DTA) expression from the Gdf7 promoter (Gdf7-DTA mice) led to a failure of the entire telencephalic $\mathrm{ChP}$ to develop, suggesting that development of the anterior domain of the telencephalic $\mathrm{ChP}$ precedes and is necessary for the development of the posterior domain. In these experiments, BMP levels were also attenuated, supporting the model that the roof plate is required to induce high levels of BMP signalling, which in turn induces posterior telencephalic ChP formation ${ }^{23}$. 
The cortical hem, a WNT-rich transient dorsal midline structure ${ }^{73-75}$, is located between the developing $\mathrm{ChP}$ and hippocampus, and is thus positioned to provide inductive signals to both neighbouring areas (FIG. 2). Defects in the cortical hem may compromise proper development of the $\mathrm{ChP}$ or hippocampus. In the zinc finger Gli3 mouse mutant extra-toes ${ }^{\mathrm{J}}$ $\left(X t^{J}\right)$, downregulation of Wnt expression in the cortical hem is accompanied by the absence of the telencephalic $\mathrm{ChP}$, but the development of the hindbrain $\mathrm{ChP}$ remains unaffected $^{73,76,77}$. Disruption of Gli3 expression in the $X t^{J}$ mutant probably contributes to the failure of the telencephalic ChP to develop, as GLI3 expressed in ChP mesenchyme may coordinate epithelial and mesenchymal interactions ${ }^{73}$. Likewise, mice lacking Dmrta2 (doublesex and mab-3 related transcription factor A2) have poorly developed cortical hem and telencephalic ChP structures, which probably result from DMRTA2 regulation of development through WNT- $\beta$-catenin signalling ${ }^{78}$. By contrast, expansion of the cortical hem may lead to an enlarged telencephalic ChP, as loss of $L h x 2$ expression in the cortex is associated with an expansion of both the cortical hem and $\mathrm{ChP}^{49,79}$.

\section{ChP epithelial cell maturation}

Upon differentiation, $\mathrm{ChP}$ epithelial cells transition through a series of stereotyped developmental stages (FIG. 3). Based on cellular morphology ${ }^{21,22}$, stage 1 is defined by a sheet of pseudostratified epithelial cells. In stage 2, these cells transition into a simple, high columnar epithelium, and in stage 3, they achieve a flattened (cuboidal) epithelial cell shape. In most species examined, stage 3 can be followed by stage 4 , depending on whether the epithelial cells have a high glycogen (energy source) content and apical or centrally positioned nuclei (in which case they remain at stage 3), or a lower glycogen content and basally positioned nuclei (in which case they progress to stage 4$)^{11,66,80}$.

Transition through these distinct stages is accompanied by structural changes such as the polarization and formation of microvilli and cilia along the apical surface, as well as changes in cellular content, including an increase in the number of mitochondria and maturation of the endoplasmic reticulum ${ }^{55,81}$. Owing to their narrow width $(\sim 50 \mathrm{~nm})$, microvilli are generally free of organelles. However, microvilli have been estimated to increase the surface area of E16 rat epithelial cells, leading to a total apical surface area of $75 \mathrm{~cm}^{2}$ for the rat telencephalic ChP; similarly, in humans, the ChP surface area is increased to $200 \mathrm{~cm}^{2} 82$. The increase in apical $\mathrm{ChP}$ surface area parallels its increased ability to produce CSF. Indeed, the machinery and enzymes required for CSF secretion are enriched in this brush border $^{83}$, suggesting that if the microvilli were damaged or ablated, CSF production by $\mathrm{ChP}$ epithelial cells would substantially decrease. Eventually with advanced age, microvilli decrease in size as does the production of $\mathrm{CSF}^{20,84,85}$.

The vast majority of $\mathrm{ChP}$ epithelial cells are multi-ciliated (9+2 microtubule configuration), with tufts of cilia ranging from 4-8 cilia per cell in rats to 50 cilia per cell in salamander ${ }^{11}$. Motile cilia are thought to contribute to CSF flow, and structural defects induced by chemical or genetic means can contribute to hydrocephalus ${ }^{86-89}$. However, epithelial cells extending one primary cilium ( $9+0$ configuration) into the CSF can also be observed in the $\mathrm{ChP}$. Although the functional significance of mono-ciliated epithelial cells remains to be elucidated, they have been proposed to play roles in osmosensation and/or chemosensation ${ }^{1}$. 


\section{Epithelial-mesenchymal interactions}

Despite cell-intrinsic mechanisms that may underlie the specification of $\mathrm{ChP}$ epithelium, extrinsic signalling through cell-cell interactions between $\mathrm{ChP}$ epithelial cells and mesenchymal cells is also necessary for both epithelial and stromal development. When grafted to the body wall, tissues containing the $\mathrm{ChP}$ anlagen are capable of maturing into tissues histologically indistinguishable from true $\mathrm{ChP}^{39}$. The epithelium forms with appropriate apico-basal polarity, microvilli architecture, and tight junctions between adjacent cells. The underlying stroma, which develops from the body wall of the host rather than from the grafted tissue, develops fenestrated capillaries, which are not typically found in the body wall ${ }^{39}$. However, the molecular mechanisms underlying the coordinated development of $\mathrm{ChP}$ epithelium and underlying vasculature are only beginning to be understood.

\section{Vascularization of the choroid plexus}

During ChP development, actively proliferating epithelial sheets envelop the underlying mesenchyme and abundant vascular supply, which raises the question of how the codevelopment of these cell types of different embryological origin is coordinated. Liveimaging of zebrafish has shown that the $\mathrm{ChP}$ epithelium makes close contact with vascular cells very early in development ${ }^{61}$. Signalling factors expressed at the roof plateneuroepithelium boundary may induce vascular differentiation in the $\mathrm{ChP}^{90}$. However, factors from the $\mathrm{ChP}$ epithelium have also been shown to regulate vascular outgrowth (FIG. 2). In particular, $S h h$, which encodes a protein known to induce angiogenesis in other tissue types, is expressed by hindbrain ChP epithelial cells, and patched 1 (Ptcl), which encodes its receptor, is highly enriched in the $\mathrm{ChP}$ mesenchyme ${ }^{91}$. Ptcl-expressing cells were identified to be chondroitin sulphate proteoglycan 4 (CSPG4; also known as NG2)expressing pericytes, which are vascular support cells that are capable of responding to ChPderived SHH and transducing this signal to regulate vascular outgrowth and surface area. However, other yet-to-be identified mechanisms control the vessel diameter and capillary fenestrations, as these parameters were normal following manipulations in SHH signalling. Indeed, the exact developmental time course of $\mathrm{ChP}$ vasculature is not well understood. Fenestrae have not been observed in E14.5 mice ${ }^{91}$. In rats, in addition to increased epithelial apical surface density, low numbers of fenestrae can be observed at E16, and they increase progressively in number per unit length of $\mathrm{ChP}$ vessel perimeter up to postnatal day $30^{82}$. These observations suggest that there is crosstalk between the developing epithelium, stroma and vasculature. Indeed, SHH that is secreted by $\mathrm{ChP}$ epithelial cells seems to regulate $\mathrm{ChP}$ epithelial production via vascular outgrowth ${ }^{91}$ as well as by directly signalling to $\mathrm{ChP}$ epithelial progenitors ${ }^{41}$.

\section{Functions of the ChP-CSF system}

The ChP has long been appreciated as the principal source of $\mathrm{CSF}^{92-94}$, and ChP epithelial cells acquire their secretory, transport and barrier functions shortly after differentiation $^{25}, 27-29,95-97$. Ion transporters at the basal and apical surfaces of $\mathrm{ChP}$ epithelial cells transport ions into CSF, and water supplied by blood is transported apically through aquaporins down an osmotic gradient ${ }^{1,98}$. Transporter expression varies 
dynamically with age ${ }^{25,26}$. Evidence in rats suggests that CSF secretion and CSF fluid volume increase dramatically during the second postnatal week and reach mature adult levels before complete maturation of the brain ${ }^{99}$. Transport across the epithelium extends beyond ions to many factors, including proteins, nutrients and metabolic precursors ${ }^{96,100}$. Myo-inositol represents one osmolyte and precursor for many signalling molecules, which is actively transported across the $\mathrm{ChP}$ epithelium by sodium/myo-inositol transporter 1 , the activity of which is regulated by potassium channel subunits KCNE2 and KCNQ1 ${ }^{101}$. Important insight into how transport across the $\mathrm{ChP}$ epithelium influences brain function comes from Kcne2-deficient mice, which are susceptible to stress and seizures, and have low levels of myo-inositol in the CSF. Dose-dependent CSF-supplementation of myo-inositol in Kcne2-deficient mice reverses their behavioural phenotypes ${ }^{101}$. The role of CSF myoinositol in psychiatric disease remains to be elucidated; however, these findings demonstrate that transport across the $\mathrm{ChP}$ epithelium can have far-reaching consequences on brain function.

ChP epithelial cells also express and secrete their own proteins into the CSF. The total CSF protein content varies with age such that it peaks near birth in rodents $35,102,103$. In other species with longer gestational periods, CSF protein content peaks in utero, suggesting that CSF protein changes are due to fundamental changes in the brain rather than birth ${ }^{104}$. Transthyretin, a thyroid hormone carrier routinely used as a marker of $\mathrm{ChP}$ epithelium, is expressed by $\mathrm{ChP}$ epithelial cells shortly after their appearance and is present in embryonic $\mathrm{CSF}^{8,21,40}$. Although some factors are directly secreted into the CSF, others are ferried via interactions with binding proteins or encapsulated in exosomes. Extracellular vesicles originating from the $\mathrm{ChP}$ transport important proteins for brain development such as folate receptor-a ${ }^{105}$, as well as non-coding RNAs, including microRNAs that regulate neural stem cells via modulation of the insulin-like growth factor (IGF) signalling pathway in an agedependent manner ${ }^{106,107}$. Ultimately, the CSF is a rich source of proteins, lipids, hormones, cholesterol, glucose, microRNAs and many other molecules and metabolites that affect a wide range of CNS functions ${ }^{2}, 12,13,21,106$. ChP functions are dynamic from development into adulthood, as protein secretion into CSF and ciliary motility continue to mature ${ }^{21,108}$.

In the developing cerebral cortex, cortical progenitor cells line the ventricular surface, extending a primary cilium directly into the CSF. The primary cilia, as well as their adjacent apical domains, harbour receptors poised to receive signals emanating from the $\operatorname{CSF}^{109}$. Indeed, pure embryonic CSF, without the addition of exogenous growth-promoting signals, promotes the development and growth of cortical progenitor cells in an age-dependent manner ${ }^{103,110}$. For instance, embryonic CSF stimulates young stem cells that are cultured as neurospheres or in tissue explants to divide vigorously. By contrast, the same stem cells bathed in older CSF, including adult CSF, undergo limited cell division. These results are consistent with findings that many protein signals in the CSF fluctuate with age. Some of the proliferative effects of embryonic CSF can be attributed to ChP-secreted IGF2 and signalling through the IGF1 receptor at the ventricular surface ${ }^{103,106,111,112}$. However, as mentioned above, the CSF is home to many signaling molecules with important roles in development (for example, fibroblast growth factors ${ }^{113}, \mathrm{SHH}^{102,114}$, retinoic acid ${ }^{115,116}$, leukaemia inhibitory factor ${ }^{117,118}$, semaphorin $3 \mathrm{~B}^{119}$ and others ${ }^{2}$ ). Thus, the construction of 
the mammalian brain depends upon the appropriate interactions of multiple signalling activities delivered to neural stem cells via the CSF.

Intriguingly in vivo, lateral and fourth ventricle CSF shows distinct protein signatures ${ }^{12,35,120}$, which are suggestive of regionalized protein gradients across the ventricular system (FIG. 4). Gene expression analyses performed in intact $\mathrm{ChP}$ as well as purified $\mathrm{ChP}$ epithelial cells from TTR::RFP mice (a random integration transgenic mouse line that expresses monomeric red fluorescent protein 1 from a transthyretin minigene) have revealed that the telencephalic and hindbrain $\mathrm{ChP}$ are spatially heterogeneous, with distinct gene expression domains that mark positional identity and encode regionalized secretomes $^{35}$. For example, the telencephalic $\mathrm{ChP}$ is enriched for markers of the posterior half of the telencephalon ${ }^{121}$ including Emx2, Otxl, and Six3, whereas the hindbrain ChP is enriched for Hox genes (for example, Hoxa and Hoxb), which is consistent with previous studies $^{53,122}$, as well as En2 and Meis ${ }^{35}$. Proteomic analyses demonstrate that this differential gene expression functionally translates to the differential secretion of nearly 200 proteins by the telencephalic and hindbrain $\mathrm{ChP}^{35}$. For example, the telencephalic $\mathrm{ChP}$ secretes higher amounts of cystatin $\mathrm{C}$ and cathepsin $\mathrm{D}$, whereas the hindbrain $\mathrm{ChP}$ secretes higher amounts of SHH, which is consistent with previous studies ${ }^{41}$, as well as proenkephalin and extracellular superoxide dismutase (EC-SOD). Regionalized ChP protein secretion occurs in an age-dependent manner, such that embryonic ChP shows robust regionalization of gene and protein expression, which decreases in adulthood, in a genespecific manner ${ }^{35}$. Spatial domains with distinct protein expression profiles were also observed within each ChP (for example, there is much higher expression of EC-SOD ventrally than dorsally within the hindbrain $\mathrm{ChP}$ ), suggesting the production of local protein gradients within a ventricle. The regionalized gene expression domains marking identity as well as its secretome (for example, SHH is both a selective marker for hindbrain $\mathrm{ChP}$ as well as a component of its secretome) are conserved in the mouse, macaque, and human brain ${ }^{35}$. Although hindbrain ChP-secreted SHH has roles in instructing hindbrain $\mathrm{ChP}^{41,91}$ and cerebellar development ${ }^{114}$, it remains to be determined whether the regional ChPsecretomes, in aggregate, also have broader roles in instructing regional brain development.

The ChP-CSF system is also emerging as a key component in the regulation of adult neurogenesis in both the ventricular-subventricular zone (V-SVZ) that is located adjacent to the lateral ventricles and the subgranular zone of the hippocampus. The landscape along the $\mathrm{V}-\mathrm{SVZ}$ is organized into pinwheels, where the neural stem cells (B cells or astrocytes) form the core of the pinwheels and are surrounded by rosettes of multi-ciliated ependymal cells ${ }^{123}$. The neural stem cells span the length of the V-SVZ, with a primary cilium that extends into the CSF and a basal domain that contacts the vascular plexus ${ }^{124,125}$. As adult neurogenesis proceeds, neural stem cells give rise to immature precursors (type $\mathrm{C}$ cells or transit amplifying cells), which ultimately generate neuroblasts (type A cells). The architecture of this germinal niche, and the unique polarity of the B cells, are thought to function as key determinants of adult neurogenesis, allowing for instructive extrinsic cues to arrive from both apical as well as basal domains.

Both embryonic and adult CSF can support adult neural stem cells that are cultured as neurospheres ${ }^{103}$, and these favourable effects of CSF are partly mediated by a combination 
of factors that are dynamically distributed in the CSF. The maintenance of adult V-SVZ architecture is crucial for its continued production of neural stem cells ${ }^{123}$. Recent studies have proposed one mechanism by which CSF-distributed factors may support the viability of this niche. ChP-secreted interleukin-1 $\beta$ binds to interleukin-1 receptors on the surface of type B neural stem cells, regulating the expression of vascular cell adhesion molecule 1 (VCAM1), a cell surface sialoglycoprotein and a member of the immunoglobulin superfamily ${ }^{126}$. VCAM1 then promotes adhesion to the neural stem cell niche and maintains niche architecture by activating NADPH oxidase 2-mediated redox homeostasis. Inhibition of VCAM1 stimulates quiescent type B cells to swiftly proliferate and advance through the cell lineage to type A neuroblasts ${ }^{126}$. An added layer of regulation to this model comes from endothelial sources of neurotrophin 3 (NT3), a neurotrophic factor with a prominent role in promoting survival. NT3 was suggested to be required for the quiescence and long-term maintenance of adult stem cells ${ }^{127}$. Originating from either the brain's vasculature or the ChP capillaries, NT3 acts as a cytostatic factor by stimulating the phosphorylation of nitric oxide synthase and production of nitric oxide in B cells ${ }^{127}$. Upon B cell differentiation into neuroblasts, SLIT in the CSF can serve as a chemo-repulsive cue that guides neuroblasts along the rostral migratory stream to the olfactory bulb ${ }^{128}$.

The role of ChP-CSF signalling in adult hippocampal neurogenesis and cognitive function has also been explored in experiments that uncovered a type 1 interferon (IFN)-dependent gene expression profile in aged $\mathrm{ChP}^{129}$. Heterochronic parabiosis, an approach in which young and old mice are surgically connected to share a blood supply ${ }^{130-132}$, was used to test whether the aged gene expression profile was due to signalling events triggered at the apical, ventricular side of the $\mathrm{ChP}$ (that is, events triggered by factors delivered by the CSF), or at the basal side of the $\mathrm{ChP}$ (that is, events triggered by factors delivered through the systemic circulation ${ }^{129}$. The results suggest that signalling events occurring at the apical and basal aspects of the ChP may modulate ChP function. Although the aged circulation did not induce expression of type I IFN-dependent genes in young $\mathrm{ChP}$, it did stimulate the expression of type II IFN-dependent genes including Ccl11, which encodes a chemokine associated with impaired plasticity. By contrast, CCL11 expression in old ChP was not mitigated by young circulation, suggesting that a complex array of brain as well as systemic signals regulate $\mathrm{ChP}$ gene expression. CSF from older animals induced a type I IFNdependent gene response in cultured ChP cells. In mouse behavioural experiments, blocking type I IFN signalling in the aged brain improved cognitive function and hippocampal neurogenesis ${ }^{129}$.

ChP-CSF based signalling has broad effects on the brain, extending beyond neurogenesis to the regulation of critical periods. For example, ChP epithelial cells synthesize and secrete the homeodomain transcription factor OTX2. OTX2 is likely to be distributed by the CSF throughout the brain and is taken up by parvalbumin-positive GABAergic interneurons in the forebrain, where it is thought to regulate interneuron maturation, and consequently the timing for the critical period of plasticity for binocular vision ${ }^{133}$. Genetic disruption of OTX2 expression in the ChP impairs the function of these forebrain circuits, enabling the reopening of binocular plasticity in primary visual cortex such that vision is restored in amblyopic mice ${ }^{134}$. In addition to the regulation of critical periods, CSF-based signalling is

Nat Rev Neurosci. Author manuscript; available in PMC 2016 February 01. 
important in the early phase of sensory map formation. The reduction of CSF serotonin levels at birth, which can be accelerated by pre-term birth, has an important role in initiating the formation of barrel fields and eye-specific segregation of the visual system ${ }^{135}$.

\title{
Summary and perspectives
}

In summary, the ChP-CSF system actively coordinates the development and health of the CNS. Although progress has been made in understanding the specification and origins of the $\mathrm{ChP}$ tissues, many questions remain unresolved. First, $\mathrm{ChP}$ epithelial cells secrete hundreds of factors into the CSF, but the regulation of gene transcription and protein translation, and the degree to which conventional versus unconventional mechanisms of protein secretion ${ }^{136}$ are engaged by the ChP remain poorly understood. Second, the identification of conserved, spatial heterogenetity across $\mathrm{ChP}$ and the secretion of regionalized $\mathrm{ChP}$ proteomes ${ }^{35}$ suggest the presence of protein gradients across the cerebroventricular system. As the CSF delivers important health- and growth-promoting signals for the developing nervous system, these findings raise questions regarding the utility and functional consequences of a regionalized CSF. Third, the model that systemic signals regulate $\mathrm{ChP}^{129}$, together with findings that CSF composition and mixing with the interstitial fluid maintain the health of the brain via convective flux more generally than previously believed ${ }^{137-139}$ (BOX 3), raise tantalizing hypotheses for the myriad ways by which CNS health can be regulated. Collectively, pairing actively evolving technologies with available models, including recently developed fluorescent ChP zebrafish lines ${ }^{140}$, should accelerate steps towards further elucidating the biology of the ChP-CSF system as well as advancing future therapies, including the transplantation of engineered $\mathrm{ChP}$ epithelial cells.

\section{Acknowledgements}

The authors thank members of the Lehtinen and Monuki laboratories for helpful discussions. The authors apologize to investigators whose work we could not reference owing to space limitations. This work was supported by CIRM RN2-00915-1 and UCI ICTS and ADRC Pilot Project Awards (to E.S.M.); and Pediatric Hydrocephalus Foundation, Alfred P. Sloan Foundation, NIH K99/R00 NS072192 and R01 NS088566 (to M.K.L.).

\section{Glossary terms}

\author{
Cribriform plate \\ The region of skull bone supporting the olfactory bulbs, which \\ is perforated to allow the passage of olfactory nerves from the \\ nasal cavities \\ Hydrocephalus \\ Neuroepithelial cells \\ A condition resulting from an excess accumulation of \\ cerebrospinal fluid within the ventricles of the brain \\ The stem cells of the nervous system, these cells initially \\ undergo symmetric division early in development to expand \\ the progenitor cell pool, and subsequently give rise to more \\ lineage-restricted cells at the start of neurogenesis, including \\ radial glial and choroid plexus epithelial cells
}




\section{Rhombic lip}

Cortical hem

Prosomeres

Rhombomeres

Bromodeoxyuridine

(BrdU)

Choroid plaque

Fenestrated capillaries

Trisomy 18

Aicardi syndrome
A transient structure located at the interface between the roof plate and dorsal neuroepithelium, which functions as a germinal epithelium and a source of diffusible signals

A signalling centre located bilaterally near the telencephalic midline, which functions as a source of WNTs and bone morphogenetic proteins for cerebral cortical, hippocampal and choroid plexus development, as well as a source of CajalRetzius cells

Segments of the anterior neural tube early in embryonic development that give rise to forebrain structures

Transient, regularly spaced repeating units of hindbrain cells in the developing embryo that will ultimately give rise to the rhombencephalon

A synthetic thymidine analog that can incorporate into replicating DNA

The non-papillary tissue at the immediate dorsal midline that separates the two choroid plexi of the lateral ventricles

Openings in the endothelium are bridged by thin diaphragms permeable to water and small molecules. (p16)

A genetic condition in which cells contain three copies of chromosome 18 rather than the normal two; also known as Edwards syndrome

A developmental disorder that is characterized by infantile spasms and defects of the corpus callosum and eyes (chorioretinopathy); see Online Mendelian Inheritance in Man 304050

\section{References}

1. Damkier HH, Brown PD, Praetorius J. Cerebrospinal fluid secretion by the choroid plexus. Physiol Rev. 2013; 93:1847-1892. [PubMed: 24137023]

2. Lehtinen MK, Walsh CA. Neurogenesis at the brain-cerebrospinal fluid interface. Annu Rev Cell Dev Biol. 2011; 27:653-679. [PubMed: 21801012]

3. Koh L, et al. Development of cerebrospinal fluid absorption sites in the pig and rat: connections between the subarachnoid space and lymphatic vessels in the olfactory turbinates. Anat Embryol (Berl). 2006; 211:335-344. [PubMed: 16528517]

4. Johnston M, Zakharov A, Koh L, Armstrong D. Subarachnoid injection of Microfil reveals connections between cerebrospinal fluid and nasal lymphatics in the non-human primate. Neuropathol Appl Neurobiol. 2005; 31:632-640. [PubMed: 16281912]

5. Mollanji R, Bozanovic-Sosic R, Zakharov A, Makarian L, Johnston MG. Blocking cerebrospinal fluid absorption through the cribriform plate increases resting intracranial pressure. Am $\mathrm{J}$ Physiol Regul Integr Comp Physiol. 2002; 282:R1593-R1599. [PubMed: 12010739]

6. Louveau A, et al. Structural and functional features of central nervous system lymphatic vessels. Nature. 2015; 523:337-341. [PubMed: 26030524] 
7. Lehtinen MK, et al. The choroid plexus and cerebrospinal fluid: emerging roles in development, disease, and therapy. J Neurosci. 2013; 33:17553-17559. [PubMed: 24198345]

8. Redzic ZB, Preston JE, Duncan JA, Chodobski A, Szmydynger-Chodobska J. The choroid plexuscerebrospinal fluid system: from development to aging. Curr Top Dev Biol. 2005; 71:1-52. [PubMed: 16344101]

9. Johanson CE, et al. Multiplicity of cerebrospinal fluid functions: New challenges in health and disease. Cerebrospinal Fluid Res. 2008; 5:10. [PubMed: 18479516]

10. Brocklehurst G. The significance of the evolution of the cerebrospinal fluid system. Ann R Coll Surg Engl. 1979; 61:349-356. [PubMed: 386891]

11. Netsky, MG.; Shuangshoti, S. The choroid plexus in health and disease. Charlottesville: University Press of Virginia; 1975.

12. Zappaterra MD, et al. A comparative proteomic analysis of human and rat embryonic cerebrospinal fluid. J Proteome Res. 2007; 6:3537-3548. [PubMed: 17696520]

13. Parada C, Gato A, Aparicio M, Bueno D. Proteome analysis of chick embryonic cerebrospinal fluid. Proteomics. 2006; 6:312-320. [PubMed: 16287170]

14. Desmond ME, Jacobson AG. Embryonic brain enlargement requires cerebrospinal fluid pressure. Dev Biol. 1977; 57:188-198. [PubMed: 863106]

15. Oi S. Classification of hydrocephalus: critical analysis of classification categories and advantages of "Multi-categorical Hydrocephalus Classification" (Mc HC). Childs Nerv Syst. 2011; 27:15231533. [PubMed: 21928018]

16. Shen MD, et al. Early brain enlargement and elevated extra-axial fluid in infants who develop autism spectrum disorder. Brain. 2013; 136:2825-2835. [PubMed: 23838695]

17. Wolburg H, Paulus W. Choroid plexus: biology and pathology. Acta Neuropathol. 2010; 119:7588. [PubMed: 20033190]

18. Zappaterra MW, Lehtinen MK. The cerebrospinal fluid: regulator of neurogenesis, behavior, and beyond. Cell Mol Life Sci. 2012; 69:2863-2878. [PubMed: 22415326]

19. Emerich DF, Skinner SJ, Borlongan CV, Vasconcellos AV, Thanos CG. The choroid plexus in the rise, fall and repair of the brain. Bioessays. 2005; 27:262-274. [PubMed: 15714561]

20. Zheng, W.; Chodobski, A. The blood-cerebrospinal fluid barrier. Boca Raton: Taylor \& Francis; 2005.

21. Dziegielewska KM, Ek J, Habgood MD, Saunders NR. Development of the choroid plexus. Microsc Res Tech. 2001; 52:5-20. [PubMed: 11135444]

22. Kappers JA. The development of the paraphysis cerebri in man with comments on its relationship to the intercolumnar tubercle and its significance for the origin of cystic tumors in the third ventricle. J Comp Neurol. 1955; 102:425-509. [PubMed: 14381543]

23. Currle DS, Cheng X, Hsu CM, Monuki ES. Direct and indirect roles of CNS dorsal midline cells in choroid plexus epithelia formation. Development. 2005; 132:3549-3559. [PubMed: 15975937] This study reveals that most epithelial cells of the ChP differentiate from GDF7-expressing roof plate cells, with the exception of the posterior domains of the telencephalic $\mathrm{ChP}$, which are induced by the roof plate in a non-cell-autonomous manner.

24. Liddelow SA, Dziegielewska KM, Vandeberg JL, Saunders NR. Development of the lateral ventricular choroid plexus in a marsupial, Monodelphis domestica. Cerebrospinal Fluid Res. 2010; 7:16. [PubMed: 20920364]

25. Liddelow SA, et al. Molecular characterisation of transport mechanisms at the developing mouse blood-CSF interface: a transcriptome approach. PLoS One. 2012; 7:e33554. [PubMed: 22457777]

26. Kratzer I, et al. Developmental changes in the transcriptome of the rat choroid plexus in relation to neuroprotection. Fluids Barriers CNS. 2013; 10:25. [PubMed: 23915922]

27. Ek CJ, Habgood MD, Dziegielewska KM, Saunders NR. Structural characteristics and barrier properties of the choroid plexuses in developing brain of the opossum (Monodelphis Domestica). J Comp Neurol. 2003; 460:451-464. [PubMed: 12717706]

28. Ek CJ, Dziegielewska KM, Stolp H, Saunders NR. Functional effectiveness of the blood-brain barrier to small water-soluble molecules in developing and adult opossum (Monodelphis domestica). J Comp Neurol. 2006; 496:13-26. [PubMed: 16528724] 
29. Johansson PA, et al. Blood-CSF barrier function in the rat embryo. Eur J Neurosci. 2006; 24:6576. [PubMed: 16800861]

30. Vogh BP, Godman DR. Timolol plus acetazolamide: effect on formation of cerebrospinal fluid in cats and rats. Can J Physiol Pharmacol. 1985; 63:340-343. [PubMed: 4005705]

31. Lindvall M, Owman C. Autonomic nerves in the mammalian choroid plexus and their influence on the formation of cerebrospinal fluid. J Cereb Blood Flow Metab. 1981; 1:245-266. [PubMed: 6276421]

32. Ellis DZ, Nathanson JA, Sweadner KJ. Carbachol inhibits $\mathrm{Na}(+)-\mathrm{K}(+)-A T P a s e$ activity in choroid plexus via stimulation of the NO/cGMP pathway. Am J Physiol Cell Physiol. 2000; 279:C1685C1693. [PubMed: 11078682]

33. Redzic ZB, Segal MB. The structure of the choroid plexus and the physiology of the choroid plexus epithelium. Adv Drug Deliv Rev. 2004; 56:1695-1716. [PubMed: 15381330]

34. Ransohoff RM, Engelhardt B. The anatomical and cellular basis of immune surveillance in the central nervous system. Nat Rev Immunol. 2012; 12:623-635. [PubMed: 22903150]

35. Lun MP, et al. Spatially heterogeneous choroid plexus transcriptomes encode positional identity and contribute to regional CSF production. J Neurosci. 2015; 35:4903-4916. [PubMed: 25810521] This study demonstrates that telencephalic $\mathrm{ChP}$ and hindbrain $\mathrm{ChP}$ are heterogeneous tissues, distinct in their transcriptional profiles and positional identities, which translates functionally into the secretion of a regionalized CSF.

36. el-Gammal S. The development of the diencephalic choroid plexus in the chick. A scanning electron-microscopic study. Cell Tissue Res. 1981; 219:297-311. [PubMed: 7273101]

37. el-Gammal S. Regional surface changes during the development of the telencephalic choroid plexus in the chick. A scanning-electron microscopic study. Cell Tissue Res. 1983; 231:251-263. [PubMed: 6850802]

38. Thomas T, Dziadek M. Capacity to form choroid plexus-like cells in vitro is restricted to specific regions of the mouse neural ectoderm. Development. 1993; 117:253-262. [PubMed: 8223250]

39. Wilting J, Christ B. An experimental and ultrastructural study on the development of the avian choroid plexus. Cell Tissue Res. 1989; 255:487-494. [PubMed: 2706656]

40. Hunter NL, Dymecki SM. Molecularly and temporally separable lineages form the hindbrain roof plate and contribute differentially to the choroid plexus. Development. 2007; 134:3449-3460. [PubMed: 17728348] This study reveals that the rhombic lip as well as distinct spatiotemporal fields of the hindbrain roof plate differentially contribute to hindbrain $\mathrm{ChP}$ development.

41. Huang X, et al. Sonic hedgehog signaling regulates a novel epithelial progenitor domainof the hindbrain choroid plexus. Development. 2009; 136:2535-2543. [PubMed: 19570847] This study identifies a SHH-responsive progenitor domain adjacent to the lower rhombic lip that regulates progenitor proliferation and hindbrain $\mathrm{ChP}$ development.

42. Li Y, Chen J, Chopp M. Cell proliferation and differentiation from ependymal, subependymal and choroid plexus cells in response to stroke in rats. J Neurol Sci. 2002; 193:137-146. [PubMed: 11790394]

43. Barkho BZ, Monuki ES. Proliferation of cultured mouse choroid plexus epithelial cells. PLoS One. 2015; 10:e0121738. [PubMed: 25815836]

44. Safaee M, et al. Choroid plexus papillomas: advances in molecular biology and understanding of tumorigenesis. Neuro Oncol. 2013; 15:255-267. [PubMed: 23172371]

45. Imayoshi I, Shimogori T, Ohtsuka T, Kageyama R. Hes genes and neurogenin regulate non-neural versus neural fate specification in the dorsal telencephalic midline. Development. 2008; 135:25312541. [PubMed: 18579678]

46. Hebert JM, Mishina Y, McConnell SK. BMP signaling is required locally to pattern the dorsal telencephalic midline. Neuron. 2002; 35:1029-1041. [PubMed: 12354394] This study demonstrates that BMP signalling at the dorsal midline has a crucial role in instructing the specification and differentiation of the telencephalic $\mathrm{ChP}$.

47. Chizhikov VV, et al. Lmx la regulates fates and location of cells originating from thecerebellar rhombic lip and telencephalic cortical hem. Proc Natl Acad Sci U S A. 2010; 107:10725-10730. [PubMed: 20498066] This study identifies LMX1A as critical for the development of the roof plate and subsequent specification of dorsal cell fates in the developing CNS. 
48. Millonig JH, Millen KJ, Hatten ME. The mouse Dreher gene Lmx1a controls formation of the roof plate in the vertebrate CNS. Nature. 2000; 403:764-769. [PubMed: 10693804]

49. Monuki ES, Porter FD, Walsh CA. Patterning of the dorsal telencephalon and cerebral cortex by a roof plate-Lhx2 pathway. Neuron. 2001; 32:591-604. [PubMed: 11719201]

50. von Frowein J, Wizenmann A, Gotz M. The transcription factors Emx1 and Emx2 suppress choroid plexus development and promote neuroepithelial cell fate. Dev Biol. 2006; 296:239-252. [PubMed: 16793035]

51. Johansson PA, et al. The transcription factor Otx2 regulates choroid plexus development and function. Development. 2013; 140:1055-1066. [PubMed: 23364326]

52. Nicholson-Flynn K, Hitchcock-DeGregori SE, Levitt P. Restricted expression of the actinregulatory protein, tropomyosin, defines distinct boundaries, evaginating neuroepithelium, and choroid plexus forerunners during early CNS development. J Neurosci. 1996; 16:6853-6863. [PubMed: 8824324]

53. Awatramani R, Soriano P, Rodriguez C, Mai JJ, Dymecki SM. Cryptic boundaries in roof plate and choroid plexus identified by intersectional gene activation. Nat Genet. 2003; 35:70-75. [PubMed: 12923530] This study developed a combinatorial recombinase-based method for fate mapping cells, revealing that the hindbrain roof plate originates from Wntl expressing rhombencephalic neuroectoderm, which gives rise to the hindbrain $\mathrm{ChP}$, and that these structures develop in a patterned, segmental manner.

54. Landsberg RL, et al. Hindbrain rhombic lip is comprised of discrete progenitor cell populations allocated by Pax6. Neuron. 2005; 48:933-947. [PubMed: 16364898]

55. Sturrock RR. A morphological study of the development of the mouse choroid plexus. J Anat. 1979; 129:777-793. [PubMed: 536314]

56. Chizhikov VV, et al. The roof plate regulates cerebellar cell-type specification and proliferation. Development. 2006; 133:2793-2804. [PubMed: 16790481]

57. Lobas MA, et al. Molecular heterogeneity in the choroid plexus epithelium: the 22-member gamma-protocadherin family is differentially expressed, apically localized, and implicated in CSF regulation. J Neurochem. 2012; 120:913-927. [PubMed: 22092001]

58. Quay WB. Regional differences in metabolism and composition of choroid plexuses. Brain Res. 1966; 2:378-389. [PubMed: 5968205]

59. Nathanson JA. beta-Adrenergic-sensitive adenylate cyclase in choroid plexus: properties and cellular localization. Mol Pharmacol. 1980; 18:199-209. [PubMed: 6252438]

60. Irvin DK, Nakano I, Paucar A, Kornblum HI. Patterns of Jagged1, Jagged2, Delta-like 1 and Deltalike 3 expression during late embryonic and postnatal brain development suggest multiple functional roles in progenitors and differentiated cells. J Neurosci Res. 2004; 75:330-343. [PubMed: 14743446]

61. Garcia-Lecea M, Kondrychyn I, Fong SH, Ye ZR, Korzh V. In vivo analysis of choroid plexus morphogenesis in zebrafish. PLoS One. 2008; 3:e3090. [PubMed: 18769618]

62. Bill BR, et al. Development and Notch signaling requirements of the zebrafish choroid plexus. PLoS One. 2008; 3:e3114. [PubMed: 18769591]

63. Dang L, et al. Notch3 signaling initiates choroid plexus tumor formation. Oncogene. 2006; 25:487-491. [PubMed: 16186803]

64. Pierfelice TJ, et al. Notch3 activation promotes invasive glioma formation in a tissue site-specific manner. Cancer Res. 2011; 71:1115-1125. [PubMed: 21245095]

65. Knudsen PA. Mode of Growth of the Choroid Plexus in Mouse Embryos. Acta Anat (Basel). 1964; 57:172-182. [PubMed: 14187980]

66. Tennyson VM, Pappas GD. Fine Structure of the Developing Telencephalic and Myelencephalic Choroid Plexus in the Rabbit. J Comp Neurol. 1964; 123:379-411. [PubMed: 14244077]

67. Furuta Y, Piston DW, Hogan BL. Bone morphogenetic proteins (BMPs) as regulators of dorsal forebrain development. Development. 1997; 124:2203-2212. [PubMed: 9187146]

68. Watanabe M, et al. BMP4 sufficiency to induce choroid plexus epithelial fate from embryonic stem cell-derived neuroepithelial progenitors. J Neurosci. 2012; 32:15934-15945. [PubMed: 23136431] This study found that BMP4 is sufficient to induce $\mathrm{ChP}$ epithelial cells from embryonic stem cell- 
derived neuroepithelial cells, which hold tremendous promise for the treatment of neurological diseases.

69. Cheng X, et al. Central roles of the roof plate in telencephalic development and holoprosencephaly. J Neurosci. 2006; 26:7640-7649. [PubMed: 16855091]

70. Panchision DM, et al. Sequential actions of BMP receptors control neural precursor cell production and fate. Genes Dev. 2001; 15:2094-2110. [PubMed: 11511541]

71. Fernandes M, Gutin G, Alcorn H, McConnell SK, Hebert JM. Mutations in the BMP pathway in mice support the existence of two molecular classes of holoprosencephaly. Development. 2007; 134:3789-3794. [PubMed: 17913790]

72. Bailey P. Morphology of the roof plate of the forebrain and the lateral choroid plexuses in the human embryo. Journal of Comparative Neurology. 1915; 26:79-120.

73. Grove EA, Tole S, Limon J, Yip L, Ragsdale CW. The hem of the embryonic cerebral cortex is defined by the expression of multiple Wnt genes and is compromised in Gli3-deficient mice. Development. 1998; 125:2315-2325. [PubMed: 9584130]

74. Louvi A, Yoshida M, Grove EA. The derivatives of the Wnt3a lineage in the central nervous system. J Comp Neurol. 2007; 504:550-569. [PubMed: 17701978]

75. Shimogori T, Banuchi V, Ng HY, Strauss JB, Grove EA. Embryonic signaling centers expressing BMP, WNT and FGF proteins interact to pattern the cerebral cortex. Development. 2004; 131:5639-5647. [PubMed: 15509764]

76. Franz T. Extra-toes (Xt) homozygous mutant mice demonstrate a role for the Gli-3 gene in the development of the forebrain. Acta Anat (Basel). 1994; 150:38-44. [PubMed: 7976186]

77. Theil T, Alvarez-Bolado G, Walter A, Ruther U. Gli3 is required for Emx gene expression during dorsal telencephalon development. Development. 1999; 126:3561-3571. [PubMed: 10409502]

78. Konno D, et al. The mammalian DM domain transcription factor Dmrta2 is required for early embryonic development of the cerebral cortex. PLoS One. 2012; 7:e46577. [PubMed: 23056351]

79. Porter FD, et al. Lhx2, a LIM homeobox gene, is required for eye, forebrain, and definitive erythrocyte development. Development. 1997; 124:2935-2944. [PubMed: 9247336]

80. Shuangshoti S, Netsky MG. Histogenesis of choroid plexus in man. Am J Anat. 1966; 118:283316. [PubMed: 5915034]

81. Dohrmann GJ. The choroid plexus: a historical review. Brain Res. 1970; 18:197-218. [PubMed: 4929003]

82. Keep RF, Jones HC. A morphometric study on the development of the lateral ventricle choroid plexus, choroid plexus capillaries and ventricular ependyma in the rat. Brain Res Dev Brain Res. 1990; 56:47-53. [PubMed: 2279331]

83. Quinton PM, Wright EM, Tormey JM. Localization of sodium pumps in the choroid plexus epithelium. J Cell Biol. 1973; 58:724-730. [PubMed: 4747925]

84. Serot JM, Foliguet B, Bene MC, Faure GC. Choroid plexus and ageing in rats: a morphometric and ultrastructural study. Eur J Neurosci. 2001; 14:794-798. [PubMed: 11576183]

85. Sturrock RR. An ultrastructural study of the choroid plexus of aged mice. Anat Anz. 1988; 165:379-385. [PubMed: 3421477]

86. Banizs B, et al. Dysfunctional cilia lead to altered ependyma and choroid plexus function, and result in the formation of hydrocephalus. Development. 2005; 132:5329-5339. [PubMed: 16284123]

87. Banizs $\mathrm{B}$, et al. Altered $\mathrm{pH}(\mathrm{i})$ regulation and $\mathrm{Na}(+) / \mathrm{HCO} 3(-)$ transporter activity in choroid plexus of cilia-defective Tg737(orpk) mutant mouse. Am J Physiol Cell Physiol. 2007; 292:C1409C1416. [PubMed: 17182727]

88. Swiderski RE, et al. Structural defects in cilia of the choroid plexus, subfornical organ and ventricular ependyma are associated with ventriculomegaly. Fluids Barriers CNS. 2012; 9:22. [PubMed: 23046663]

89. Narita K, Kawate T, Kakinuma N, Takeda S. Multiple primary cilia modulate the fluid transcytosis in choroid plexus epithelium. Traffic. 2010; 11:287-301. [PubMed: 19958467] 
90. Broom ER, Gilthorpe JD, Butts T, Campo-Paysaa F, Wingate RJ. The roof plate boundary is a bidirectional organiser of dorsal neural tube and choroid plexus development. Development. 2012; 139:4261-4270. [PubMed: 23052907]

91. Nielsen CM, Dymecki SM. Sonic hedgehog is required for vascular outgrowth in the hindbrain choroid plexus. Dev Biol. 2010; 340:430-437. [PubMed: 20123094]

92. Cushing H. Studies on the Cerebro-Spinal Fluid : I. Introduction. J Med Res. 1914; 31:1-19. [PubMed: 19972189]

93. Dandy WE. Experimental Hydrocephalus. Annals of Surgery. 1919; 70:129-142. [PubMed: 17864139]

94. Dandy WE, Blackfan KD. An Experimental and Clinical Study of Internal Hydrocephalus. Journal of the American Medical Association. 1913; 61:2216-2217.

95. Johansson PA, et al. Aquaporin-1 in the choroid plexuses of developing mammalian brain. Cell Tissue Res. 2005; 322:353-364. [PubMed: 16133142]

96. Liddelow SA, et al. Cellular transfer of macromolecules across the developing choroid plexus of Monodelphis domestica. Eur J Neurosci. 2009; 29:253-266. [PubMed: 19200232]

97. Ek CJ, et al. Efflux mechanisms at the developing brain barriers: ABC-transporters in the fetal and postnatal rat. Toxicol Lett. 2010; 197:51-59. [PubMed: 20466047]

98. Brown PD, Davies SL, Speake T, Millar ID. Molecular mechanisms of cerebrospinal fluid production. Neuroscience. 2004; 129:957-970. [PubMed: 15561411]

99. Bass NH, Lundborg P. Postnatal development of bulk flow in the cerebrospinal fluid system of the albino rat: clearance of carboxyl-( 14 C)inulin after intrathecal infusion. Brain Res. 1973; 52:323332. [PubMed: 4739806]

100. Liddelow SA, et al. Modification of protein transfer across blood/cerebrospinal fluid barrier in response to altered plasma protein composition during development. Eur J Neurosci. 2011; 33:391-400. [PubMed: 21138490]

101. Abbott GW, et al. KCNQ1, KCNE2, and Na+-coupled solute transporters form reciprocally regulating complexes that affect neuronal excitability. Sci Signal. 2014; 7:ra22. [PubMed: 24595108]

102. Dziegielewska KM, et al. Proteins in cerebrospinal fluid and plasma of fetal sheep during development. J Physiol. 1980; 300:441-455. [PubMed: 6155467]

103. Lehtinen MK, et al. The cerebrospinal fluid provides a proliferative niche for neural progenitor cells. Neuron. 2011; 69:893-905. [PubMed: 21382550] This study showed that secreted factors in the CSF, including ChP-secreted IGF2, regulate cerebral cortical progenitor cell proliferation and brain development.

104. Ek, CJ.; Dziegielewska, KM.; Saunders, NR. Development of the Blood-Cerebrospinal Fluid Barrier. Zheng, W.; Chodobski, A., editors. Boca Raton: Taylor \& Francis; 2005.

105. Grapp M, et al. Choroid plexus transcytosis and exosome shuttling deliver folate into brain parenchyma. Nat Commun. 2013; 4:2123. [PubMed: 23828504]

106. Feliciano DM, Zhang S, Nasrallah CM, Lisgo SN, Bordey A. Embryonic cerebrospinal fluid nanovesicles carry evolutionarily conserved molecules and promote neural stem cell amplification. PLoS One. 2014; 9:e88810. [PubMed: 24533152]

107. Tietje A, Maron KN, Wei Y, Feliciano DM. Cerebrospinal Fluid Extracellular Vesicles Undergo Age Dependent Declines and Contain Known and Novel Non-coding RNAs. PLoS One. 2014; 9:e113116. [PubMed: 25420022]

108. Nonami Y, Narita K, Nakamura H, Inoue T, Takeda S. Developmental changes in ciliary motility on choroid plexus epithelial cells during the perinatal period. Cytoskeleton (Hoboken). 2013; 70:797-803. [PubMed: 23959957]

109. Louvi A, Grove EA. Cilia in the CNS: the quiet organelle claims center stage. Neuron. 2011; 69:1046-1060. [PubMed: 21435552]

110. Zappaterra MW, LaMantia AS, Walsh CA, Lehtinen MK. Isolation of cerebrospinal fluid from rodent embryos for use with dissected cerebral cortical explants. J Vis Exp. 2013:e50333. [PubMed: 23524481]

111. Higginbotham $\mathrm{H}$, et al. Arl13b-regulated cilia activities are essential for polarized radial glial scaffold formation. Nat Neurosci. 2013; 16:1000-1007. [PubMed: 23817546] 
112. Yeh $\mathrm{C}$, et al. IGF-1 activates a cilium-localized noncanonical Gbetagamma signaling pathway that regulates cell-cycle progression. Dev Cell. 2013; 26:358-368. [PubMed: 23954591]

113. Martin C, et al. FGF2 plays a key role in embryonic cerebrospinal fluid trophic properties over chick embryo neuroepithelial stem cells. Dev Biol. 2006; 297:402-416. [PubMed: 16916506]

114. Huang X, et al. Transventricular delivery of Sonic hedgehog is essential to cerebellar ventricular zone development. Proc Natl Acad Sci U S A. 2010; 107:8422-8427. [PubMed: 20400693]

115. Yamamoto M, McCaffery P, Drager UC. Influence of the choroid plexus on cerebellar development: analysis of retinoic acid synthesis. Brain Res Dev Brain Res. 1996; 93:182-190. [PubMed: 8804705]

116. Chang JT, Lehtinen MK, Sive H. Zebrafish cerebrospinal fluid mediates cell survival through a retinoid signaling pathway. Dev Neurobiol. 2015

117. Hatta T, et al. Quantitative analyses of leukemia inhibitory factor in the cerebrospinal fluid in mouse embryos. Neuroreport. 2006; 17:1863-1866. [PubMed: 17179859]

118. Gregg C, Weiss S. CNTF/LIF/gp130 receptor complex signaling maintains a VZ precursor differentiation gradient in the developing ventral forebrain. Development. 2005; 132:565-578. [PubMed: 15634701]

119. Arbeille E, et al. Cerebrospinal fluid-derived Semaphorin3B orients neuroepithelial cell divisions in the apicobasal axis. Nat Commun. 2015; 6:6366. [PubMed: 25721514]

120. Cavanagh ME, et al. Comparison of proteins in CSF of lateral and IVth ventricles during early development of fetal sheep. Brain Res. 1983; 313:159-167. [PubMed: 6199091]

121. Puelles L, Rubenstein JL. Expression patterns of homeobox and other putative regulatory genes in the embryonic mouse forebrain suggest a neuromeric organization. Trends Neurosci. 1993; 16:472-479. [PubMed: 7507621]

122. Philippidou P, Dasen JS. Hox genes: choreographers in neural development, architects of circuit organization. Neuron. 2013; 80:12-34. [PubMed: 24094100]

123. Mirzadeh Z, Merkle FT, Soriano-Navarro M, Garcia-Verdugo JM, Alvarez-Buylla A. Neural stem cells confer unique pinwheel architecture to the ventricular surface in neurogenic regions of the adult brain. Cell Stem Cell. 2008; 3:265-278. [PubMed: 18786414]

124. Doetsch F, Caille I, Lim DA, Garcia-Verdugo JM, Alvarez-Buylla A. Subventricular zone astrocytes are neural stem cells in the adult mammalian brain. Cell. 1999; 97:703-716. [PubMed: 10380923]

125. Fuentealba LC, Obernier K, Alvarez-Buylla A. Adult neural stem cells bridge their niche. Cell Stem Cell. 2012; 10:698-708. [PubMed: 22704510]

126. Kokovay E, et al. VCAM1 is essential to maintain the structure of the SVZ niche and acts as an environmental sensor to regulate SVZ lineage progression. Cell Stem Cell. 2012; 11:220-230. [PubMed: 22862947]

127. Delgado AC, et al. Endothelial NT-3 Delivered by Vasculature and CSF Promotes Quiescence of Subependymal Neural Stem Cells through Nitric Oxide Induction. Neuron. 2014; 83:572-585. [PubMed: 25043422] This study showed that NT3 secreted by both brain and ChP capillaries regulates adult neurogenesis.

128. Sawamoto K, et al. New neurons follow the flow of cerebrospinal fluid in the adult brain. Science. 2006; 311:629-632. [PubMed: 16410488] This study identified gradients of CSF proteins - in particular, SLIT - that influence the migration of newly born adult neurons.

129. Baruch K, et al. Aging-induced type I interferon response at the choroid plexus negatively affects brain function. Science. 2014 This study identified an ageing-induced IFN response in the ChP and that the modulation of this response can influence cognitive function.

130. Villeda SA, et al. The ageing systemic milieu negatively regulates neurogenesis and cognitive function. Nature. 2011; 477:90-94. [PubMed: 21886162]

131. Conboy IM, et al. Rejuvenation of aged progenitor cells by exposure to a young systemic environment. Nature. 2005; 433:760-764. [PubMed: 15716955]

132. Katsimpardi L, et al. Vascular and neurogenic rejuvenation of the aging mouse brain by young systemic factors. Science. 2014; 344:630-634. [PubMed: 24797482]

133. Sugiyama $S$, et al. Experience-dependent transfer of Otx 2 homeoprotein into the visual cortex activates postnatal plasticity. Cell. 2008; 134:508-520. [PubMed: 18692473] 
134. Spatazza J, et al. Choroid-plexus-derived otx 2 homeoprotein constrains adult cortical plasticity. Cell Rep. 2013; 3:1815-1823. [PubMed: 23770240] This study identified the ChP as the source of OTX2, which is taken up by interneurons in the forebrain to regulate binocular vision and critical periods.

135. Toda $\mathrm{T}$, et al. Birth regulates the initiation of sensory map formation through serotonin signaling. Dev Cell. 2013; 27:32-46. [PubMed: 24135230]

136. Nickel W, Rabouille C. Mechanisms of regulated unconventional protein secretion. Nat Rev Mol Cell Biol. 2009; 10:148-155. [PubMed: 19122676]

137. Xie L, et al. Sleep drives metabolite clearance from the adult brain. Science. 2013; 342:373-377. [PubMed: 24136970]

138. Iliff JJ, et al. A paravascular pathway facilitates CSF flow through the brain parenchyma and the clearance of interstitial solutes, including amyloid beta. Sci Transl Med. 2012; 4:147ra111. Using in vivo two-photon imaging of superficial regions in the cerebral cortex, this study showed CSF entry into the brain along para-arterial spaces, whereas interstitial fluid and soluble amyloid- $\beta$ were cleared along the brain's paravenous pathways, all in an astrocyte-and aquaporin 4dependent manner.

139. Iliff JJ, et al. Cerebral arterial pulsation drives paravascular CSF-interstitial fluid exchange in the murine brain. J Neurosci. 2013; 33:18190-18199. [PubMed: 24227727]

140. Henson HE, Parupalli C, Ju B, Taylor MR. Functional and genetic analysis of choroid plexus development in zebrafish. Front Neurosci. 2014; 8:364. [PubMed: 25426018]

141. Prinz M, Priller J. Microglia and brain macrophages in the molecular age: from origin to neuropsychiatric disease. Nat Rev Neurosci. 2014; 15:300-312. [PubMed: 24713688]

142. Monier A, Evrard P, Gressens P, Verney C. Distribution and differentiation of microglia in the human encephalon during the first two trimesters of gestation. J Comp Neurol. 2006; 499:565582. [PubMed: 17029271]

143. Cunningham CL, Martinez-Cerdeno V, Noctor SC. Microglia regulate the number of neural precursor cells in the developing cerebral cortex. J Neurosci. 2013; 33:4216-4233. [PubMed: 23467340]

144. Tremblay ME, et al. The role of microglia in the healthy brain. J Neurosci. 2011; 31:1606416069. [PubMed: 22072657]

145. Pont-Lezica L, Bechade C, Belarif-Cantaut Y, Pascual O, Bessis A. Physiological roles of microglia during development. J Neurochem. 2011; 119:901-908. [PubMed: 21951310]

146. Steffen BJ, Breier G, Butcher EC, Schulz M, Engelhardt B. ICAM-1, VCAM-1, and MAdCAM-1 are expressed on choroid plexus epithelium but not endothelium and mediate binding of lymphocytes in vitro. Am J Pathol. 1996; 148:1819-1838. [PubMed: 8669469]

147. Kunis G, et al. IFN-gamma-dependent activation of the brain's choroid plexus for CNS immune surveillance and repair. Brain. 2013; 136:3427-3440. [PubMed: 24088808]

148. Schwartz M, Baruch K. The resolution of neuroinflammation in neurodegeneration: leukocyte recruitment via the choroid plexus. EMBO J. 2014; 33:7-22. [PubMed: 24357543]

149. Shechter R, et al. Recruitment of beneficial M2 macrophages to injured spinal cord is orchestrated by remote brain choroid plexus. Immunity. 2013; 38:555-569. [PubMed: 23477737]

150. Shechter R, London A, Schwartz M. Orchestrated leukocyte recruitment to immune-privileged sites: absolute barriers versus educational gates. Nat Rev Immunol. 2013; 13:206-218. [PubMed: 23435332]

151. Demasio K, et al. Isolated choroid plexus cyst in low-risk women less than 35 years old. Am J Obstet Gynecol. 2002; 187:1246-1249. [PubMed: 12439513]

152. Greenfield, JG.; Love, S.; Louis, DN.; Ellison, D. Greenfield's neuropathology. London: Hodder Arnold; 2008.

153. Tavani F, Zimmerman RA, Clancy RR, Licht DJ, Mahle WT. Incidental intracranial hemorrhage after uncomplicated birth: MRI before and after neonatal heart surgery. Neuroradiology. 2003; 45:253-258. [PubMed: 12687311]

154. van Rybroek JJ, Moore SA. Sudden death from choroid plexus vascular malformation hemorrhage: case report and review of the literature. Clin Neuropathol. 1990; 9:39-45. [PubMed: 2407402] 
155. Naeini RM, Yoo JH, Hunter JV. Spectrum of choroid plexus lesions in children. AJR Am J Roentgenol. 2009; 192:32-40. [PubMed: 19098176]

156. Tong Y, et al. Cross-Species Genomics Identifies TAF12, NFYC, and RAD54L as Choroid Plexus Carcinoma Oncogenes. Cancer Cell. 2015; 27:712-727. [PubMed: 25965574]

157. Hirano $\mathrm{H}$, et al. Hydrocephalus due to villous hypertrophy of the choroid plexus in the lateral ventricles. Case report. J Neurosurg. 1994; 80:321-323. [PubMed: 8283272]

158. Fujimura M, et al. Hydrocephalus due to cerebrospinal fluid overproduction by bilateral choroid plexus papillomas. Childs Nerv Syst. 2004; 20:485-488. [PubMed: 14986042]

159. Smith ZA, et al. Choroid plexus hyperplasia: surgical treatment immunohistochemical results. Case report. J Neurosurg. 2007; 107:255-262. [PubMed: 17918538]

160. Davis JD, Tremont G. Neuropsychiatric aspects of hypothyroidism and treatment reversibility. Minerva Endocrinol. 2007; 32:49-65. [PubMed: 17353866]

161. Davis JD, Stern RA, Flashman LA. Cognitive and neuropsychiatric aspects of subclinical hypothyroidism: significance in the elderly. Curr Psychiatry Rep. 2003; 5:384-390. [PubMed: 13678560]

162. Fleming CE, Nunes AF, Sousa MM. Transthyretin: more than meets the eye. Prog Neurobiol. 2009; 89:266-276. [PubMed: 19665514]

163. Serot JM, Bene MC, Faure GC. Choroid plexus, aging of the brain, and Alzheimer's disease. Front Biosci. 2003; 8:s515-s521. [PubMed: 12700093]

164. Hladky SB, Barrand MA. Mechanisms of fluid movement into, through and out of the brain: evaluation of the evidence. Fluids Barriers CNS. 2014; 11:26. [PubMed: 25678956] 


\section{Box 1}

\section{Immune cells in the choroid plexus}

The choroid plexus (ChP) is home to a variety of immune cells, including $\mathrm{ChP}$ macrophages, dendritic cells and Kolmer's epiplexus cells, and also provides a port of entry for immune cells into the CNS. Macrophages and dendritic cells are located primarily in the $\mathrm{ChP}$ stroma, whereas Kolmer's epiplexus cells reside along the apical, ventricular side of the $\mathrm{ChP}$ epithelium, where they probably function as local antigenpresenting cells to lymphocytes ${ }^{34}$. ChP macrophages are thought to derive from the haematopoietic stem cell-derived myeloid cells that are produced at mouse embryonic day 10.5 (E10.5) in the aorta-gonad-mesonephros region or by E12.5 in the fetal liver ${ }^{141}$. Although immune cell function in the developing $\mathrm{ChP}$ has not been extensively investigated to date, the $\mathrm{ChP}$ may serve as a port for microglia to enter first the cerebrospinal fluid (CSF) and then the brain at the ventricular surface. In human fetal brain, ionized calcium binding adaptor molecule 1 (IBA1)-expressing microglia are found in close proximity to the developing $\mathrm{ChP}$ as early as 5.5 gestational weeks ${ }^{142}$. Once in the developing brain, microglia regulate several important processes including cortical progenitor cell numbers, neuronal plasticity and circuit function ${ }^{143-145}$.

Although the mechanisms regulating immune cell passage across the developing $\mathrm{ChP}$ are not well understood, it is a task that probably involves the tight regulation of numerous intercellular signalling events, as has been shown for adult tissues. For example, in the adult $\mathrm{ChP}$, infiltrating immune cells first migrate from the blood across the fenestrated endothelium into the stromal space. They then move along the basolateral surface of the $\mathrm{ChP}$ epithelium, from where they gain passage across the epithelium into the CSF-filled ventricles ${ }^{34}$. Indeed, recent studies show that the $\mathrm{ChP}$ expresses adhesion molecules and chemokines including intercellular adhesion molecule 1 and interferons, which facilitate the transepithelial passage of leukocytes into the $\mathrm{CSF}^{146-150}$. Secreted signals distributed in the CSF (for example. interleukin-13, interleukin-10 and transofmring growth factor- $\beta$ ) then serve as instructive cues to attract macrophages to sites of injury such as the spinal cord $^{149}$. In the developing brain, the sources and signals that instruct immune cells to cross the $\mathrm{ChP}$ and enable them to identify target sites of action remain to be elucidated.

Historically, the CNS has been considered immune privileged. The immune cell content of healthy CSF is estimated to consist of approximately $90 \%$ T cells, $5 \%$ B cells, $5 \%$ monocytes, and $<1 \%$ dendritic cells ${ }^{34}$. We now know that immune cells in the CSF patrol the CNS, antigens in the CNS can trigger adaptive immune responses, and unbridled immune responses in the CNS can develop into chronic immunopathological conditions such as multiple sclerosis. An improved understanding of the mechanisms underlying immune-ChP interactions in the developing and mature brain should enable the development of new therapies for a wide range of nervous system disorders. 


\section{Box 2}

\section{Pathologies of the human choroid plexus}

Although not particularly well studied, human choroid plexus (ChP) pathologies are not uncommon. During development, $\mathrm{ChP}$ pathologies include cysts (see the figure), haemorrhages, diffuse villous hyperplasia and tumours. ChP cysts are common in the developing fetus (estimated 1-2\% incidence) but generally resolve on their own. These cysts occur with increased frequency in trisomies, particularly trisomy 18 (33-50\% incidence), and in certain syndromes, such as Aicardi syndrome (see the figure). When a $\mathrm{ChP}$ cyst is seen in the absence of other trisomy-associated stigmata, the risk of trisomy for pregnant women under 35 is extremely low ${ }^{151}$. ChP haemorrhages (see the figure) tend to occur in term rather than premature infants ( $>35$ weeks gestation $)^{152}$. Although these can be seen in otherwise uncomplicated term deliveries ${ }^{153}$, ChP haemorrhages are often associated with perinatal stress or hypoxia-ischaemia, in addition to factors such as trauma and anticoagulation therapy. Vascular malformations can also cause $\mathrm{ChP}$ haemorrhage ${ }^{154}$. In infants and children, microorganisms (for example, bacteria in neonatal meningitis) can use the $\mathrm{ChP}$ for primary colonization and CNS entry via the cerebrospinal fluid (CSF) and ventricular system ${ }^{152}$.

Abnormal ChP proliferative lesions take the form of diffuse villous hyperplasia, benign papillomas and malignant carcinomas. Although ChP tumours represent less than $1 \%$ of brain tumours overall, they represent $2-4 \%$ of brain tumours in children and $10-20 \%$ of tumors in the first year of life. ChP carcinomas (see the figure) are seen mainly in the lateral ventricles of children (mostly between $2-4$ years of age) ${ }^{155}$, whereas adult $\mathrm{ChP}$ tumours are most often papillomas of fourth ventricle. ChP papillomas and carcinomas ${ }^{156}$ have relatively complex cytogenetic abnormalities (multiple chromosome gains and losses) but display different cytogenetic patterns, suggesting distinct pathways in the pathogenesis of papillomas versus carcinomas. Diffuse villous hyperplasia and $\mathrm{ChP}$ tumours can lead to hydrocephalus because of CSF overproduction, which can be treated by cauterization or resection ${ }^{157-159}$. Other tumours seen in the $\mathrm{ChP}$ include meningiomas, lipomas, xanthogranulomas and rare metastases. Although meningiomas (which arise from meningeal arachnoidal cells) occur commonly on the surface of the brain, meningiomas can also occur in the $\mathrm{ChP}$, presumably arising from tela choroidea where meningeal cells abut the ventricular lining. 
Aicardi syndrome with ChP cyst

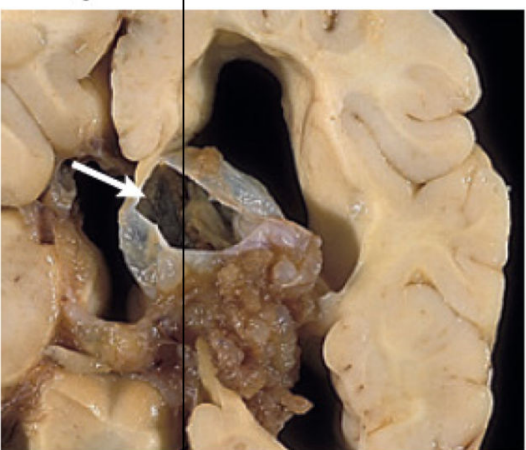

Neonatal brain with

ChP haemorrhage

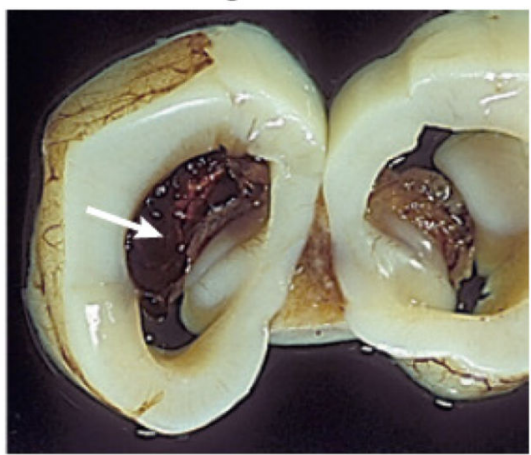

ChP carcinoma with papillary formations

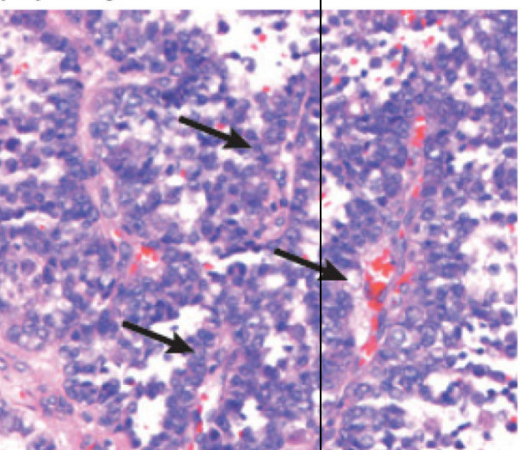

ChP pathology is increasingly implicated in cognitive and neurodegenerative disorders as well. Unlike blood, which has three major carrier-distributor proteins for thyroid hormone, the CNS has only one major thyroid hormone carrier-distributor, namely ChPderived transthyretin. Accordingly, CNS deficiencies in thyroid hormone - which are linked to abnormal brain development, adult dementia, depression and other cognitive problems ${ }^{160,161}$ — can be due to systemic hypothyroidism or ChP transthyretin defects. The ChP is also central to at least three different mechanisms for clearing amyloid- $\beta$ (A $\beta$ ) peptides, which are implicated in the pathophysiology of Alzheimer disease (AD): CSFmediated $\mathrm{A} \beta$ clearance, direct $\mathrm{A} \beta$ absorption, and $\mathrm{A} \beta$ chaperone and protease production. $\mathrm{AD}$ is associated with accelerated atrophy of the $\mathrm{ChP}^{19,162,163}$, which plausibly leads to decreased $A \beta$ clearance via these three mechanisms. This possibility has led multiple groups to suggest a causal role for ChP atrophy in AD. Notably, accelerated ChP atrophy has also been described in stroke, multiple sclerosis, schizophrenia and other CNS diseases, raising the possibility that accelerated ChP atrophy exacerbates multiple CNS diseases. Viral-mediated gene delivery to the $\mathrm{ChP}$ and $\mathrm{ChP}$ epithelial cell generation from human embryonic stem cells ${ }^{68}$ provides hope for ChP-targeted therapies and drug screens to combat ChP pathologies and to enable ChP-CSF-based delivery of therapeutic compounds throughout the CNS. 


\section{Box 3}

\section{Cerebrospinal fluid exchange and flux}

In addition to distributing secreted signals throughout the ventricular system, the cerebrospinal fluid (CSF) has an important role in clearing the brain of toxins and waste. Recent work using two-photon imaging in mice through a cranial window, which allows for imaging of the superficial cerebral cortex, led to a model in which a tripartite clearance mechanism contributes to clearing waste in the brain. Named the "glymphatic" system, aquaporin 4 channels on astrocytic end feet first facilitate the para-arterial CSF influx into the brain's parenchyma ${ }^{138}$. This convective flux of CSF and interstitial fluid (ISF), with the aid of arterial pulsatility ${ }^{139}$, then flushes parenchymal waste via an intercellular trans-astrocytic path into the paravenous space for eventual clearance into the systemic circulation. Radiolabel tracer studies estimate that $40-80 \%$ of proteins and solutes in the extracellular space of superficial cortex may be removed in this manner, with the clearance of amyloid- $\beta$ being one of the most intriguing noted to date. In these studies, the ISF space was estimated to increase by more than $60 \%$ during natural sleep or anaesthesia ${ }^{137}$. These findings suggest new potential roles for sleep and CSF fluid mechanics in maintenance of brain health. However, many questions remain to be addressed in future studies ${ }^{164}$. 


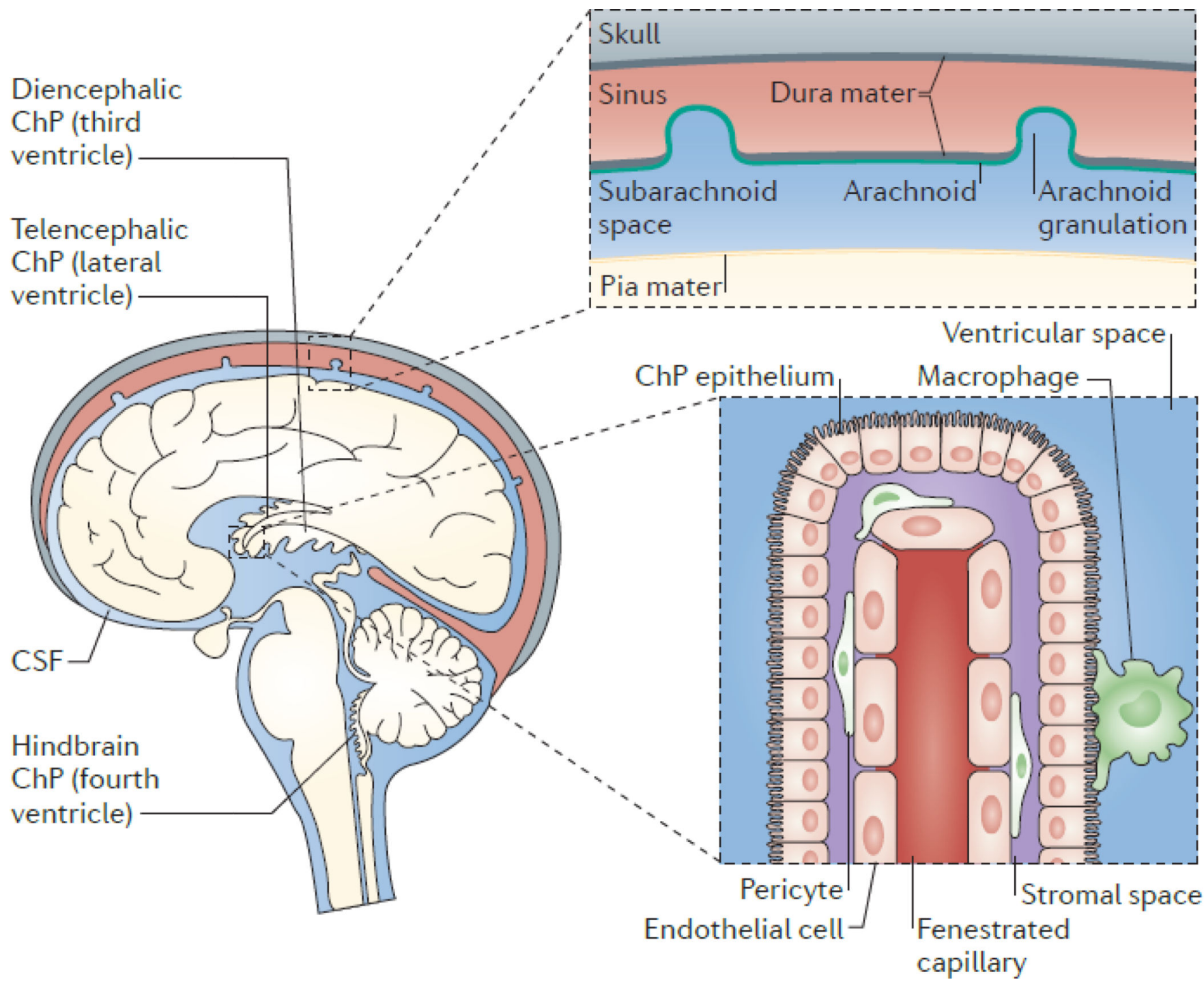

Figure 1. The choroid plexus-cerebrospinal fluid system

The choroid plexus (ChP) consists of epithelial cells that surround a core of capillaries and connective tissue. The epithelial cells are joined by tight junctions, which form the bloodcerebrospinal fluid (CSF) barrier. The ChP is located in each ventricle in the brain, and is regarded as the principal source of CSF, secreting up to $500 \mathrm{ml}$ of CSF per day in the adult human brain. CSF flows from the lateral to the third ventricle through the interventricular foramina, and from the third to the fourth ventricle through the cerebral aqueduct. CSF can then enter the central canal of the spinal cord or the subarachnoid space, where microscopic arachnoid villi and macroscopic arachnoid granulations (granulations are present in humans and other large mammals), together with lymphatics present in the cribriform plateolfactory region ${ }^{3-5}$ or lining the meninges-dural sinuses (6 - Louveau), resorb CSF into the systemic circulation or into regional and cervical lymph nodes. The $\mathrm{ChP}$ is organized into an outer layer of cuboidal epithelial cells surrounding a core of fenestrated capillaries and other stromal cell types. Functioning as the blood-CSF barrier, the ChP is also a gateway for immune cell entry into the central nervous system (BOX 1). 
a Hindbrain ChP development
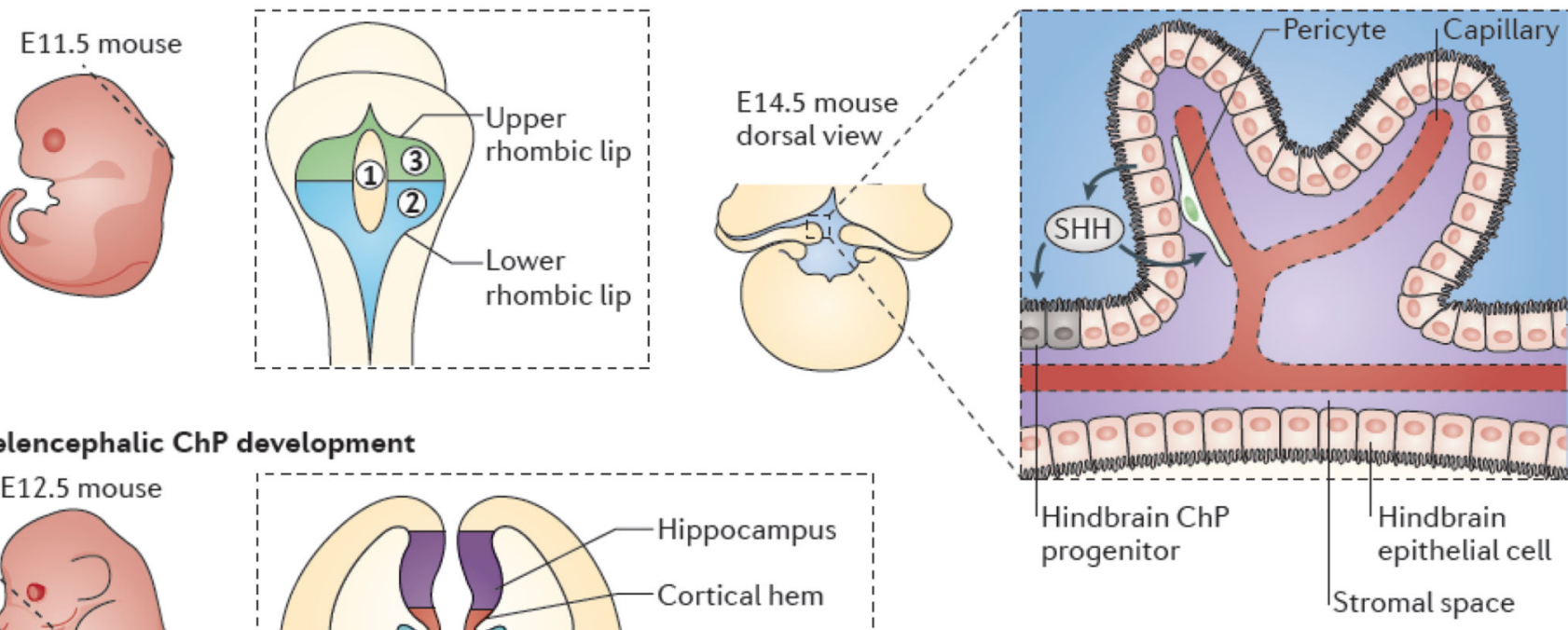

b Telencephalic ChP development
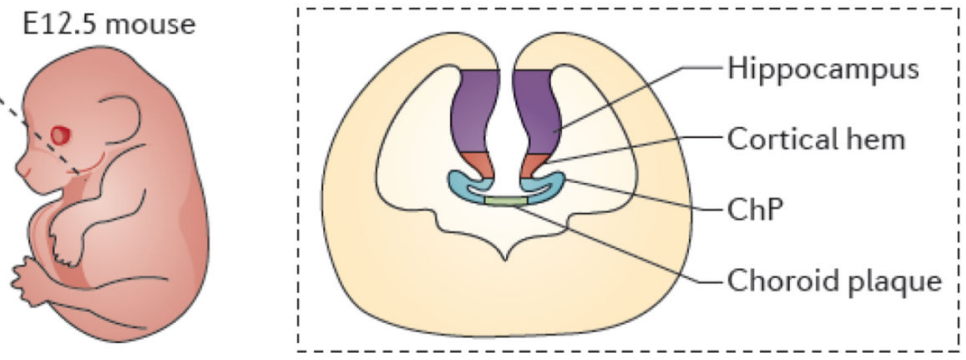

Hindbrain

tromal space

Figure 2. Progenitor domains of the hindbrain and telencephalic choroid plexi

a Hindbrain choroid plexus (ChP) development begins at about embryonic day 9.5 (E9.5) and peaks between $\sim$ E11 and E12. The left panel shows a sagittal view of mouse embryo at E11.5; the dashed line represents idealized field of view for the middle panel, which shows a dorsal view of the neural tube. The rhombic lip neuroepithelium (gray) surrounds three fields of hindbrain roofplate epithelium. Field 1 (yellow) contains cells that do not express transthyretin (Ttr) or potassium voltage-gated channel subfamily E member 2 (Kcne2), whereas field 2 (blue) contains caudally derived (from rhombomeres 2-8) Ttr- and Kcne2positive cells and field 3 (green) contains rostrally derived (from rhombomere 1) Ttr- and Kcne2-positive cells ${ }^{40}$. The right panel depicts the dorsal view of a proliferating $\mathrm{ChP}$, as it emerges from the lateral edges of the fourth ventricle and grows medially to complete its development by E14. Sonic hedgehog (SHH) that is secreted by hindbrain ChP epithelial cells (black) signals to underlying pericytes ${ }^{91}$ (green) to regulate vascular outgrowth (red) while also signalling to hindbrain $\mathrm{ChP}$ progenitors adjacent to the lower rhombic lip to induce further progenitor proliferation ${ }^{41}$ (inset). $\mathbf{b} \mid$ Development of telencephalic $\mathrm{ChP}$ follows that of the hindbrain $\mathrm{ChP}$. The left panel shows a sagittal view of a mouse embryo at E12.5, in which the dashed line represents the idealized coronal section that is shown in the right panel. The right panel depicts a telencephalic $\mathrm{ChP}$ developing bilaterally at the invaginated dorsal midline of the neural tube. Telencephalic $\mathrm{ChP}$ formation requires signals from the dorsal midline, including bone morphogenetic proteins and WNTs originating from the cortical hem. Disruption of the dorsal midline is frequently associated with either $\mathrm{ChP}$ over proliferation or failure of the $\mathrm{ChP}$ to form. 


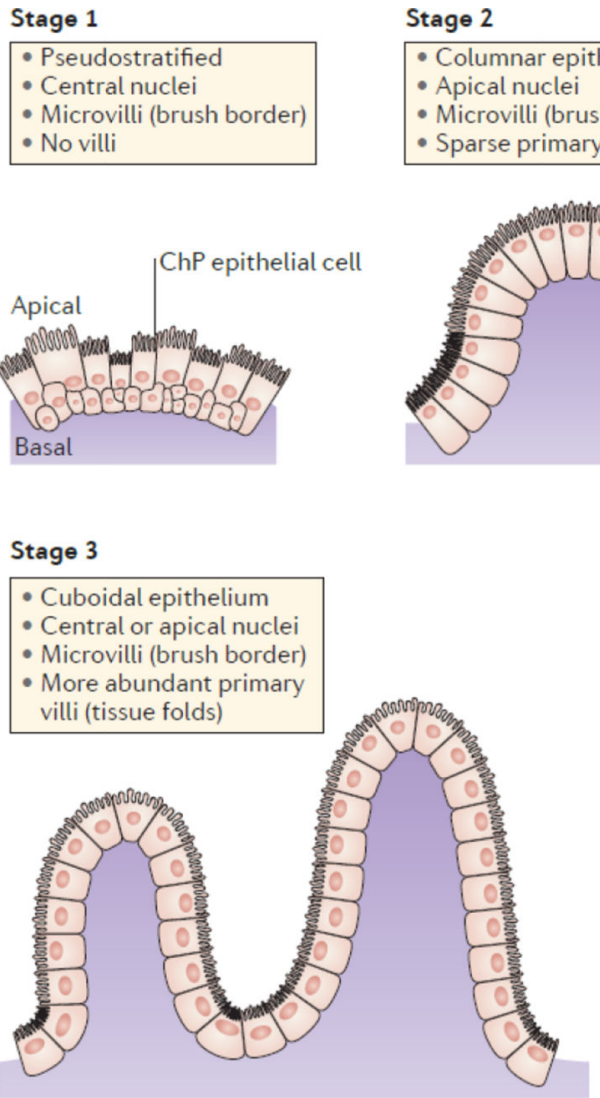

- Columnar epithelium - Apical nuclei

- Microvilli (brush border)

- Sparse primary villi (tissue folds)

\section{Stage 4}

- Cuboidal epithelium - Basal nuclei

- Microvilli (brush border)

- Complex villi (multiple tissue folds)

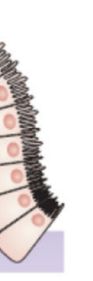

Figure 3. Morphological stages of the developing choroid plexus epithelium

The choroid plexus $(\mathrm{ChP})$ of each ventricle has the same morphology and is organized into a layer of cuboidal epithelium surrounding a core of vasculature and other stromal cells. The maturation of epithelial cells includes four stereotypical stages. The $\mathrm{ChP}$ epithelial cells first appear to be pseudostratified with centrally located nuclei in stage 1 with little to no villous elaboration. This is followed by a transition to a columnar epithelium with apically located nuclei in stage 2 , and the tissue becomes convoluted into sparse primary villi. In stage 3 , the epithelial cells flatten to become more cuboidal in shape, nuclei are centrally or apically located, and primary villi in the tissue become more abundant. Last, in stage 4, nuclei become more basally located, which is thought to be caused by the apical enrichment of transport machinery and microvilli, and villi are more complex with multiple fronds. Junctions and adhesion molecules are found between adjacent cells, allowing the mature $\mathrm{ChP}$ to function as the blood-cerebrospinal fluid (CSF) barrier by restricting the passage of solutes from systemic circulation into CSF. 
Telencephalic ChP

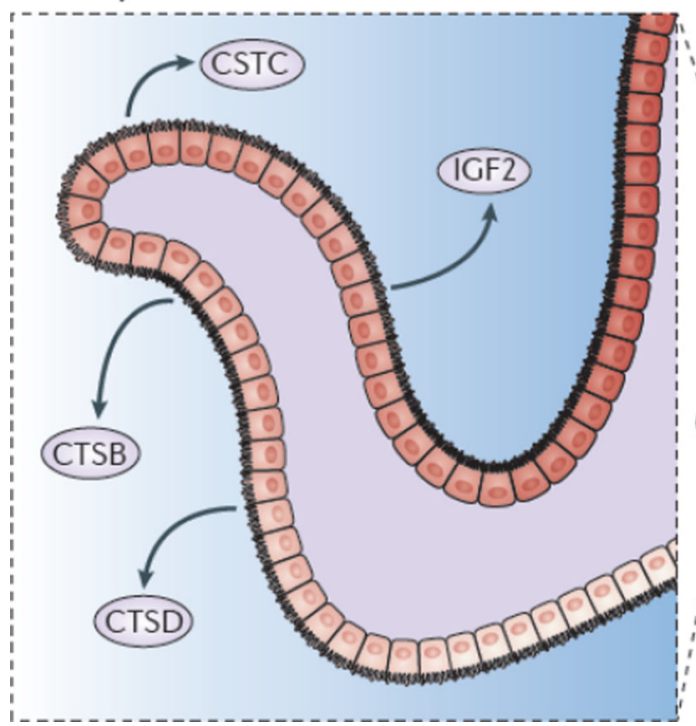

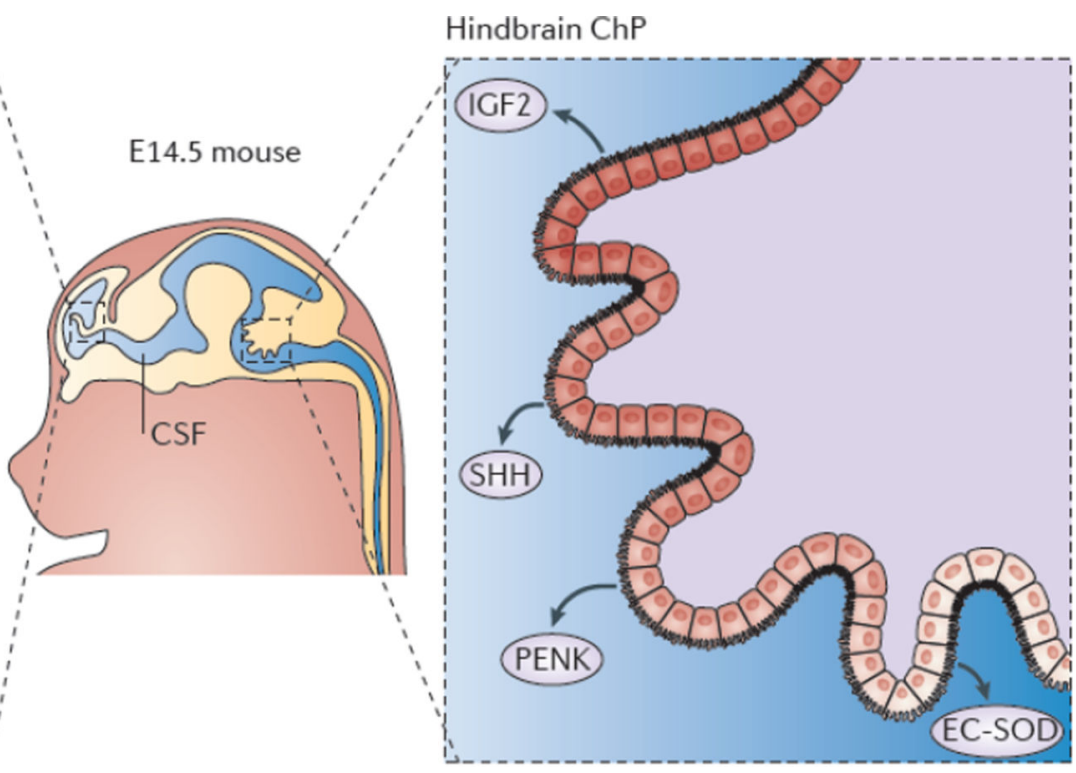

Figure 4. Telencephalic and hindbrain choroid plexi are transcriptionally and functionally distinct tissues

Gene expression profiling of mouse and primate telencephalic choroid plexus (ChP) and hindbrain ChP reveal that, despite being morphologically similar, these tissues are transcriptionally heterogeneous ${ }^{35}$. The ChPs maintain distinct positional identities reminiscent of their axial tissues of origin. The telencephalic $\mathrm{ChP}$ has higher expression levels of Emx2Otxl, and Six3, which are markers of the telencephalon, whereas the hindbrain $\mathrm{ChP}$ has higher expression levels of Hoxa2En2, and Meis1, genes critical for patterning the hindbrain. Further analysis of the ChP secretome reveals that these tissues are functionally distinct in their expression and secretion of signalling factors into the cerebrospinal fluid $(\mathrm{CSF})^{35}$. In particular, the telencephalic $\mathrm{ChP}$ secretes more cystatin $\mathrm{C}$ (CSTC), cathepsin B (CTSB) and cathepsin D (CTSD), whereas the hindbrain ChP secretes more Sonic hedgehog (SHH), proenkephalin (PENK) and extracellular superoxidedismutase (EC-SOD). Protein expression domains have been observed within each $\mathrm{ChP}$ (for example, EC-SOD ${ }^{35}$ and $\mathrm{SHH}^{53}$ protein domains), which is suggestive of protein gradients within each ventricle. These findings indicate that the molecular heterogeneity of the telencephalic versus the hindbrain ChP contributes to establishing a regionalized CSF and support a model of protein gradients throughout the ventricular system. 